Review Article

\title{
Sustainable and Dynamic Competitiveness towards Technological Leadership of Industry 4.0: Implications for East African Community
}

\author{
Ocident Bongomin ${ }^{\mathbb{D}},{ }^{1}$ Eric Oyondi Nganyi, ${ }^{1}$ Mfanga Ramadhani Abswaidi, ${ }^{2}$ \\ Emmanuel Hitiyise, ${ }^{3}$ and Godias Tumusiime ${ }^{1,4}$ \\ ${ }^{1}$ Department of Manufacturing, Industrial and Textile Engineering, School of Engineering, Moi University, P.O. Box 3900-30100, \\ Eldoret, Kenya \\ ${ }^{2}$ Department of Information and Communication Technology, Moshi Co-operative University, P.O. Box 474, Moshi, Tanzania \\ ${ }^{3}$ Department of Electrical and Electronics Engineering, College of Science and Technology, University of Rwanda, P.O. Box 3900, \\ Kigali, Rwanda \\ ${ }^{4}$ Department of Polymer, Industrial and Textile Engineering, Faculty of Engineering, Busitema University, P.O. Box 236, Tororo, Uganda
}

Correspondence should be addressed to Ocident Bongomin; ocidentbongomin@gmail.com

Received 14 April 2020; Revised 12 May 2020; Accepted 13 May 2020; Published 1 June 2020

Academic Editor: Di He

Copyright (c) 2020 Ocident Bongomin et al. This is an open access article distributed under the Creative Commons Attribution License, which permits unrestricted use, distribution, and reproduction in any medium, provided the original work is properly cited.

\begin{abstract}
The war to technology and economic powers has been the driver for industrialization in most developed countries. The first industrial revolution (industry 1.0) earned millions for textile mill owners, while the second industrial revolution (industry 2.0) opened the way for tycoons and captains of industry such as Henry Ford, John D. Rockefeller, and J.P. Morgan. The third industrial revolution (industry 3.0) engendered technology giants such as Apple and Microsoft and made magnates of men such as Bill Gates and Steve Jobs. Now, the race for the fourth industrial revolution (industry 4.0) is on and there is no option, and every country whether developed or developing must participate. Many countries have positively responded to industry 4.0 by developing strategic initiatives to strengthen industry 4.0 implementation. Unlocking the country's potential to industry 4.0 has been of interest to researchers in the recent past. However, the extent to which industry 4.0 initiatives are being launched globally has never been divulged. Therefore, the present study aimed at exploring industry 4.0 initiatives through a comprehensive electronic survey of the literature to estimate the extent of their launching in different regions. Inferences were drawn from industry 4.0 initiatives in developed nations to be used as the recommendations for the East African Community. Results of the survey revealed that 117 industry 4.0 initiatives have been launched in 56 countries worldwide consisting of five regions: Europe (37\%), North America (28\%), Asia and Oceania (17\%), Latin America and the Caribbean (10\%), and Middle East and Africa (8\%). The worldwide percentage was estimated as $25 \%$. This revealed that there is a big gap existing between countries in the race for industry 4.0 .
\end{abstract}

\section{Introduction}

The race towards industry 4.0 is on [1], and it is crucial that the East African Community (EAC) must participate [2,3]. Unlike the previous industrial revolutions where Africa was left out, industry 4.0 is fast, disruptive, and destructive to all industrial sectors including healthcare, education, and finance [4], and thus Africa cannot escape [5]. For this reason, every country must join the revolution either way [6]. Most importantly, it requires early and strong preparation from every country to be successful. In addition, industry 4.0 is developing at an astounding pace and high speed, while creating a lot of great opportunities. Therefore, if countries do not get ready, industry 4.0 will increase the visibility of inequalities among them including companies and people (i.e., the have and have-nots, the skilled and unskilled, and 
the rich and the poor). This depicts that attempting to maintain the status quo is not an option for any region, country, or company $[6,7]$.

Germany emerged the first country to put forward the idea of industry 4.0, focusing on engineering excellence to dilate its strengths in engineering and machine building to informatization [8]. Japan egressed as the robotic superpower, and it is strategizing on integrating robots with Internet of things (IoT) and M2M technologies under the umbrella "Robot Revolution Initiative (RRI)" [9]. On the other hand, the US is the world leader in information technology and it focuses on increasing its strengths to robotization, commonly known as Industrial Internet or industrial Internet of things (IIoT). The IIoT involves integration and linking of big data, analytical tools, and wireless networks with physical and industrial equipment [10]. However, nowadays, the concept of industry 4.0 has expanded tremendously and its definition spans beyond engineering, smart and connected machines, and systems. Its waves of disruption and destruction are also breakthroughs in areas ranging from gene sequencing to nanotechnology, renewable energy to quantum computing, and simulation to $3 \mathrm{D}$ printing of objects (buildings to body organs) $[11,12]$. Simply put, industry 4.0 is the fusion of disruptive technologies and their interaction across the virtual, physical, digital, and biological domains making it rudimentarily unique from previous revolutions [13]. In other words, industry 4.0 is an intelligent manufacturing, digitalization, automation, and robotization, as well as e-commercialization of the economy [2, 14-16]. Its wave of disruptive transformation includes "digital transformation," "circular economy," and "bio-based system," each of which will occur at different periods [17]. A number of countries are apparently embracing digital transformation and thus the first transformational wave of industry 4.0. The main characteristics of industry 4.0 include interoperability, visualization, decentralization, real-time capability, service orientation, modularity, convergence, cost reduction, efficiency, and mass customization [18].

Industry 4.0 is a collective term for disruptive technologies and concepts of value chain organization [19] and a wave of disruptions and uncertainties with a core of industrial transformation, revitalization, and development [20]. This has escalated global competitions among developed and developing countries. Therefore, one of the survival strategies is for the governments to establish critical programs that can drastically change the global structures of major industrial sectors [21]. This is because industrialization remains emblematic to long-term development ambition for developing and least-developed countries, and it is indispensable for competitiveness [22, 23]. However, the wealthy or developed countries view industrialization at different angles; they are doing it intelligently through public policies that promote innovation [23]. For instance, three approaches used by the leading manufacturing nations towards the adoption of industry 4.0 has been divulged $[24,25]$. These approaches were labeled as "coordinated" for Germany [26], "managed" for China, and "market-driven" for the US to reflect the government's role towards industry
4.0 effectuation in a country $[23,27]$. Because there is no set formula or single scheme for the execution of industry 4.0 technologies, companies are generally adopting industry 4.0 technologies specific to the requirements of their businesses [28, 29].

Despite the enormous negative impacts of industry 4.0 on almost everything, there are numerous benefits that come with its adoption. For instance, the benefits identified to change the fundamental equation of manufacturing can be classified into six categories: competitiveness, productivity, profitability, revenue, traceability, and record keeping [1]. Competition has reached unprecedented phases globally, and the industrial structure is rapidly changing with important foreign investments, including those of emerging economies in Europe, the US, and China [17, 30]. In the current competition dilemma, it is not just a matter of being a winner but also maintaining a leadership position through clear focus and coordinated efforts to invest in industry 4.0 technologies [31-33]. In addition, organizations or policy makers should think strategically when determining where to focus and invest, so as to build their capabilities in manufacturing $[34,35]$. Moreover, exciting the domestic competitiveness in manufacturing is emblematic to global competitiveness of the country. Therefore, there is a dire need for developing new approaches and transformational roadmaps for integrating the industry 4.0 infrastructure in small and medium enterprises (SMEs) $[36,37]$.

Todays' manufacturing landscape is full of uncertainties with ever-changing demands, greater customization, smaller lot sizes, sudden supply-chain changes, and disruptions. It is a complex heterogeneous ecosystem with a broader range of actors, including companies (SMEs), technology and material suppliers, universities, training centres, research and technology organizations, customers, and consumers. Therefore, sustainable manufacturing will have to be merged with industry 4.0 technologies $[38,39]$. These technologies including Internet of things, Big data, and Blockchain are reshaping business dynamics [11, 12]. Consequently, all countries regardless of their levels of development need to coordinate their policies and tools to benefit from these technologies. Moreover, the rapid convergence of these technologies is not only reshaping production and consumption but also redefining the competitive landscape [40-42]. Innovative manufacturing is a central lineament of industry 4.0 , and businesses will need to compete with one another by lowering costs and improving efficiency in the use of technology [43]. The reality is that manufacturing embraces a wider range of activities beyond production, and therefore fortifying manufacturing sectors is indispensable for the global sustainable competitiveness [44-46].

As one way to strengthen industry 4.0 deployment and penetration in countries, national strategic initiatives have been launched by governments, private sectors, or publicprivate partnerships. However, the extent of industry 4.0 initiatives that have been launched in different countries worldwide remains unclear. In order to unlock this, the current study was conducted to compare the different industry 4.0 initiatives launched by different countries. In addition, it aimed at identifying these initiatives from 
developed and developing countries in comparison to the EAC and derived a suitable recommendation to strengthen industry 4.0 adaptation in the EAC alongside the existing ICT policy. As industry 4.0 is a convergence of every sector, this paper was intended to reach a large audience including political and corporate leaders, policy makers, academia, industry, and the society at large.

\section{Methodology}

A comprehensive literature search was conducted in electronic databases: Google Scholar, Science Direct, Scopus, Sage, Taylor \& Francis, Springer, and Emerald Insight from January 2020 to April 2020 following procedures employed in previous studies $[11,47]$. The search was performed independently in all the databases and then combined with "and" operators. The multidisciplinary databases included original research peer-reviewed journal articles, books, theses, dissertations, working papers, white papers, discussion papers, patents, and reports covering concepts on industry 4.0 initiatives between 2011 and 2020. Thus, articles in the returned results were assessed concerning their inclusion in this study, and further searches were carried out at the Google search engine. The first online literature search was done using the search term "Industry 4.0 initiative." Because of the manageable criteria, all the relevant literatures were downloaded (PDF files) and saved on the computer. However, only important literature that focused and contained the industry 4.0 initiative(s) were considered for the in-depth search on industry 4.0 initiatives of a specific country (Figure 1). Basically, the first online literature search was done to get an overview of the industry 4.0 initiatives launched around the world. More focalized searches were then conducted with the following search terms: "industry 4.0 initiative and Germany," "Industry 4.0 initiative and China," "Industry 4.0 initiative and United States," "Industry 4.0 initiative and India," "Industry 4.0 initiative and Mexico," "Industry 4.0 and Japan," "Digital Strategy 2025," "High-Tech Strategy 2025," "Manufacturing USA," "Society 5.0," "Made in China 2025," "Make in India," "Crafting the Future," "East African Community or EAC," "East African Community and industry 4.0 initiative," "Rwanda and industry 4.0 initiative," "Kenya and industry 4.0 initiative," "Uganda and industry 4.0 initiative," "Tanzania and industry 4.0 initiative," "Burundi and industry 4.0," "South Sudan and industry 4.0" "ICT and Rwanda," "ICT and Kenya," "ICT and Uganda," "ICT and Tanzania," "ICT and Burundi," and "ICT and South Sudan." The last search was done on 10 April 2020. The search outputs were saved on databases, and the authors received notification of any new searches meeting the search criteria (from Science Direct, Scopus, and Google Scholar).

\section{Results and Discussion}

3.1. Industry 4.0 Initiatives Overview. In the electronic survey, only policies, programs, strategies, or plans developed between 2011 and 2020 and focusing on industry 4.0 were considered as industry 4.0 initiatives. The industry 4.0

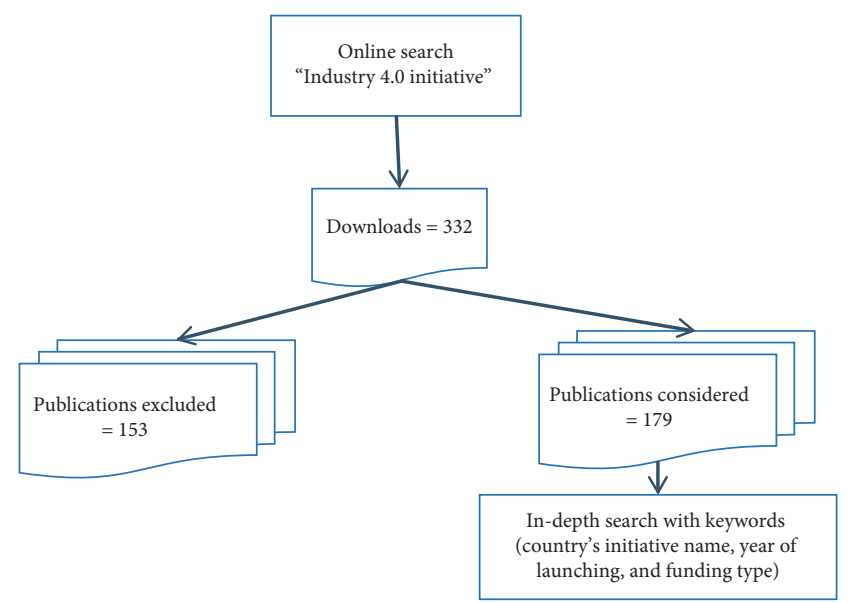

FIGURE 1: Flowchart illustrating the literature search strategy used.

initiatives launched by 56 countries and international cooperation around the world were identified in the published literature. The countries were categorized into 5 regions for the purpose of quantitative analysis. These regions included: (i) Latin America and the Caribbean region with 15 national industry 4.0 initiatives for 7 countries (Table 1); (ii) North America with 7 initiatives for 2 countries (Table 2); (iii) Europe region has 41 initiatives for 25 countries aspresented in Table 3; (iv) Asia and Oceania region has 39 initiatives for 14 countries as shown in Table 4; and (v) Middle East and Africa region has 15 initiatives for 8 countries as presented in Table 5. Besides, Table 6 shows 6 initiatives for 4 regional and international cooperation.

The number of countries and the total number of industry 4.0 initiatives launched per region are depicted in Table 7. For statistical analysis, the list of countries was adopted from that prepared by "Population Division of the United Nations Department of Economic and Social Affairs" [143]. The total number of countries per region, and the total of countries with industry 4.0 initiatives and their percentage are summarized in Table 7. Figure 2 illustrates that Europe (37\%) leads the rest of the regions in launching industry 4.0 initiatives, followed by North America (28\%), Asia and Oceania (17\%), Latin America and the Caribbean (10\%), and Middle East and Africa (8\%). The overall percentage of countries with industry 4.0 initiatives was estimated as $25 \%$. Evidence from this study shows that European countries are progressing faster than the rest of the world in adopting industry 4.0. This could be because of the strong international cooperation (European Union) with focalized industry 4.0 policies. As demonstrated, every region as well as country is adopting industry 4.0 at their own pace. This is due to the fact that launching industry 4.0 initiatives and technological developments require huge finances and resources. For this reason, the inequality is very visible among countries and regions, as developed nations are not limited with finances unlike developing countries. This is supported by the fact that Europe has more economically and technologically advanced countries than the rest of the regions combined [144-147]. 
Table 1: Industry 4.0 initiatives in Latin America and the Caribbean.

\begin{tabular}{|c|c|c|c|c|c|}
\hline $\mathrm{S} / \mathrm{N}$ & Country & Industry 4.0 initiatives & Year & Funding & Reference(s) \\
\hline \multirow{4}{*}{1} & \multirow{4}{*}{ Brazil } & New national strategy on industry 4.0 or Industry 4.0 roadmap & 2013 & Public & {$[48]$} \\
\hline & & Brazilian digital strategy (E-Digital) or Brasil Eficiente & 2018 & Public & {$[49,50]$} \\
\hline & & Working group for I4.0 (WGI4.0) & 2017 & Public & [22] \\
\hline & & Prosoft 4.0 & 2018 & Public & {$[51]$} \\
\hline \multirow[t]{3}{*}{2} & \multirow[t]{2}{*}{ Mexico } & Crafting the future $(\mathrm{CF})$ & 2016 & $\begin{array}{l}\text { Public- } \\
\text { private }\end{array}$ & {$[52]$} \\
\hline & & Nuevo Léon 4.0 (NL4.0) & 2018 & Public & {$[53]$} \\
\hline & \multirow{3}{*}{ Argentina } & National innovation & 2017 & Public & {$[51]$} \\
\hline \multirow[t]{2}{*}{3} & & Digital industry 4.0 plan & 2018 & Public & {$[51]$} \\
\hline & & R\&D innovation clusters & 2017 & Public & {$[51]$} \\
\hline \multirow{2}{*}{4} & \multirow{2}{*}{ Colombia } & Production transformation programme & 2016 & Public & {$[51]$} \\
\hline & & Micro and SMEs Live Digital (MiPyme vive Digital) & 2014 & Public & {$[40]$} \\
\hline 5 & Paraguay & Vision Paraguay 2030 & 2014 & Public & {$[51]$} \\
\hline \multirow{2}{*}{6} & Dominican & Competitiveness improvement plan & 2014 & Public & {$[51]$} \\
\hline & Republic & SMEs Digital Economy Plan & 2015 & Public & {$[51]$} \\
\hline 7 & Chile & $\begin{array}{c}\text { Strategic Programme Smart Industries (Programa Estratégico Industrias } \\
\text { Inteligentes (PEII)) }\end{array}$ & 2015 & Public & {$[22]$} \\
\hline
\end{tabular}

TABle 2: Industry 4.0 initiatives launched in North America.

\begin{tabular}{|c|c|c|c|c|c|}
\hline $\mathrm{S} / \mathrm{N}$ & Country & Industry 4.0 initiatives & Year & Funding & Reference(s) \\
\hline \multirow{5}{*}{1} & \multirow{5}{*}{ US } & Smart Manufacturing Leadership Coalition (SMLC) or Smart Manufacturing & 2012 & $\begin{array}{l}\text { Public- } \\
\text { private }\end{array}$ & {$[54-56]$} \\
\hline & & AMP and $2^{\text {nd }}$ Advanced Manufacturing Partnership (AMP 2.0) & $\begin{array}{c}2012 \& \\
2014\end{array}$ & Public & {$[31,57-59]$} \\
\hline & & $\begin{array}{c}\text { National Network for Manufacturing Innovation (NNMI) and } \\
\text { Manufacturing USA (MUSA) }\end{array}$ & $\begin{array}{c}2012 \& \\
2016\end{array}$ & $\begin{array}{l}\text { Public- } \\
\text { private }\end{array}$ & {$[60,61]$} \\
\hline & & Hollings Manufacturing Extension Program (HMEP) & 2017 & Public & {$[46,62-65]$} \\
\hline & & Industrial Internet Consortium (IIC) or industrial internet of things & 2014 & Private & {$[66-71]$} \\
\hline \multirow{2}{*}{2} & \multirow{2}{*}{ Canada } & Industrie 2030 & 2016 & Public & [72] \\
\hline & & Centre for Smart Manufacturing (CSM) & 2015 & Public & {$[73,74]$} \\
\hline
\end{tabular}

3.2. Comparison of Industry 4.0 Initiatives. Further literature search and study were conducted to understand the differences existing between the different industry 4.0 initiatives that have been launched in different countries. In order to narrow the scope of the literature searches, six countries were selected from which six initiatives were selected and compared in terms of their goals and industry 4.0 technologies focus areas. As illustrated in Figure 3, Germany, US, China, and Japan were selected because of their outstanding economic and technology powers [89]. While India and Mexico were also selected because of their unprecedented technological leapfrogging in the $21^{\text {st }}$ century. It was quoted that these two countries were able to "jump" directly from industry 2.0 to industry 4.0 [148]. Evidently, it was necessary to compare each of them with the economic power countries. Due to the fact that each country has launched more than one industry 4.0 initiative, only recently launched initiative(s) in each country was selected for this study: the "Digital Strategy 2025 and High-Tech Strategy 2025 (DS \& HTS 2025)" from Germany, "Manufacturing USA (MUSA)" from the US, "Made in China 2025 (MIC 2025)" from China, "Society 5.0" from Japan, "Make in India" from India, and "Crafting the future" from Mexico. The compounding of
HTS 2025 and DS 2025 in this study is due to the fact that both initiatives have the same timeline, and HTS 2025 is the successor of Germany's new High-Tech Strategy [149]. Therefore, their combined strength can be well compared with other country's initiatives.

3.2.1. Digital Strategy 2025 and High-Tech Strategy 2025. Digital Strategy 2025 and High-Tech Strategy 2025 (DS \& HTS 2025) are two complementary industry 4.0 programs that have been launched recently. The Digital Strategy 2025 initiative was launched in 2016 under the German Federal Ministry for Economic Affairs and Energy (BMWi) [90]. Its central focus is on digitizing everything, including the products [150] and small and medium-scale enterprises (SMEs) to attain a competitive advantage [151]. It also aimed at enabling the German economy in responding to new challenges and enhancing its competitiveness both in quality and technology, by combining traditional competitive advantages with the newest technology, modern methods, and specific support programmes [90]. Germany was quick to realize their digitization weakness in the industry sectors (automotive, machine tools, chemicals, and 
TABle 3: Industry 4.0 initiatives launched in Europe.

\begin{tabular}{|c|c|c|c|c|c|}
\hline $\mathrm{S} / \mathrm{N}$ & Country & Industry 4.0 strategic initiatives & Year & Funding & Reference(s) \\
\hline \multirow{4}{*}{1} & \multirow{4}{*}{$\begin{array}{l}\text { United } \\
\text { Kingdom }\end{array}$} & High Value Manufacturing Catapult (HVMC) or Catapult centres & 2013 & Public & [27] \\
\hline & & Digital Academy (DA) or UK Digital Strategy & 2017 & Public & {$[1]$} \\
\hline & & National Innovation Plan (NIP) & 2016 & Public & [72] \\
\hline & & Innovate UK (future of manufacturing (FOM)) & 2013 & Public & {$[72]$} \\
\hline \multirow{3}{*}{2} & \multirow{3}{*}{ France } & $\begin{array}{c}\text { Industrie du futur (IdF) or alliance pour l'industrie du futur (AIdF) or } \\
\text { Industry of the Future }\end{array}$ & 2015 & Public & {$[26,75]$} \\
\hline & & La Nouvelle France industrielle (LNFI) or new France industry (NFI) & 2013 & Public & {$[26,76]$} \\
\hline & & French Fab (FF) (Made in France) & 2017 & Public & [27] \\
\hline \multirow{2}{*}{3} & \multirow{2}{*}{ Italy } & Piano Nazionale Industria 4.0 or Piano Impressa 4.0 & 2016 & Public & [77] \\
\hline & & Intelligent factory clusters (CFI) (Fabbrica intelligente) & 2012 & Private & [26] \\
\hline 4 & Portugal & PRODUCTECH & 2015 & Public & [26] \\
\hline \multirow{2}{*}{5} & \multirow{2}{*}{ Sweden } & Made in Sweden 2030 & 2014 & Public & [78] \\
\hline & & Produktion 2030 & 2013 & Public & {$[26,79]$} \\
\hline 6 & Belgium & Made Different & 2013 & Public & {$[26,74]$} \\
\hline 7 & Switzerland & Industry 2025 & 2015 & Public & [10] \\
\hline 8 & Netherlands & Smart Industry & 2014 & Public & {$[74,79]$} \\
\hline \multirow{2}{*}{9} & \multirow{2}{*}{ Finland } & Industrial Internet Business Revolution & 2015 & Public & [80] \\
\hline & & IoT Pilot Factory (IoT PFF) & 2017 & Public & {$[80]$} \\
\hline 10 & Poland & Future Industry Platform & 2015 & Public & {$[81]$} \\
\hline 11 & Czech Republic & Prumysl 4.0 & 2013 & Public & {$[26,81]$} \\
\hline \multirow{2}{*}{12} & \multirow{2}{*}{ Estonia } & Digital Agenda 2020 & 2015 & Public & {$[82]$} \\
\hline & & E-society Estonia & 2012 & Public & {$[82]$} \\
\hline 13 & Croatia & Digitization Impulse 2020-industry of the future & 2016 & Public & {$[24]$} \\
\hline 14 & Latvia & Demola (Riga IT TechHub) & 2017 & Public & {$[26]$} \\
\hline 15 & Demark & MADE & 2012 & Public & {$[26,80]$} \\
\hline 16 & Hungary & IPAR 4.0 National technology platform/Irinyi plan & 2017 & Public & [81] \\
\hline 17 & Bulgaria & Kontseptsia Industria 4.0 & 2017 & Public & [81] \\
\hline 18 & Romania & National Strategy for Romania Digital Agenda 2020 & 2017 & Public & [81] \\
\hline \multirow[t]{2}{*}{19} & Lithuania & Pramone 4.0 & 2017 & Public & {$[81]$} \\
\hline & \multirow{3}{*}{ Austria } & TUWin 4.0 & 2013 & Public & {$[32]$} \\
\hline \multirow[t]{2}{*}{20} & & Platform Industry 4.0 & 2014 & Public & {$[32]$} \\
\hline & & Industry 4.0 Austria & 2015 & Public & {$[32]$} \\
\hline 21 & Slovenia & Slovenia Digital Coalition/Slovenia Industrial Policy 2013 & 2013 & Public & [81] \\
\hline 22 & Slovakia & Smart Industry Platform & 2016 & Public & {$[26,81]$} \\
\hline 23 & Ireland & Ireland's Industry 4.0 Strategy & 2019 & Public & [83] \\
\hline \multirow{4}{*}{24} & \multirow{4}{*}{ Spain } & Industria Conectada 4.0 & 2017 & Public & {$[26,72]$} \\
\hline & & 5G Digital Agenda & 2018 & Public & {$[40]$} \\
\hline & & Industrie 4.0 (I4.0) and Plattform Industrie 4.0 (PI4.0) & $\begin{array}{c}2011 \& \\
2013\end{array}$ & $\begin{array}{l}\text { Public- } \\
\text { private }\end{array}$ & {$[39,84-87]$} \\
\hline & & Mittelstand 4.0 & 2012 & $\begin{array}{l}\text { Public- } \\
\text { private }\end{array}$ & {$[88,89]$} \\
\hline \multirow[t]{3}{*}{25} & \multirow[t]{3}{*}{ Germany } & Digital Strategy (DS) 2025 and High-Tech Strategy (HTS) 2025 & $\begin{array}{c}2016 \& \\
2018\end{array}$ & Public & {$[88,90]$} \\
\hline & & AI Strategy & 2018 & Public & {$[88]$} \\
\hline & & $\begin{array}{c}\text { Shaping digitalization implementation strategy for the federal } \\
\text { government (SDISFG) }\end{array}$ & 2018 & Public & {$[88,91]$} \\
\hline
\end{tabular}

pharmaceuticals) over its competitors (USA, Japan, and China) [152]. This has triggered the launch of the Digital Strategy 2025 to knead alongside the existing initiatives (industrie 4.0 and Mittelstand 4.0) so that the German economy remains competitive. Germany launched another initiative called the "High-Tech Strategy 2025" in September 2018 as the strategic framework for research and innovation policy [153]. They reasoned that ability to gain sustainable competitiveness is focalized around strengthening education, research, and innovation. HTS 2025 aims at scaling up investment in research and development [153]. It also focuses on leveraging key society challenges, namely, healthcare sustainability, climate protection and energy, mobility, urban and rural areas, safety and security, and economy and work 4.0. The intention is to shape the economy, working life, and lifestyles by creating a universal environment for harnessing the competitiveness, the preservation of the natural life-support systems, and social equity [153]. This is quite similar to the goal of Japanese Society 5.0 initiative. However, HTS 2025 is being driven by a missionoriented approach to bring together the activities of the ministries involved in the fields of action and relevant 
TABLE 4: Industry 4.0 initiatives launched in Asia and Oceania.

\begin{tabular}{|c|c|c|c|c|c|}
\hline $\mathrm{S} / \mathrm{N}$ & Country & Industry 4.0 initiatives & Year & Funding & References \\
\hline \multirow{4}{*}{1} & \multirow{4}{*}{ China } & Made in China 2025 (MIC 2025) & 2015 & Public & {$[41,92]$} \\
\hline & & Internet Plus $(+)$ & 2015 & Public-private & {$[93,94]$} \\
\hline & & Belt and Road Initiative (BRI) & 2013 & Public & {$[95-99]$} \\
\hline & & $13^{\text {th }}$ five-year plan $\left(13^{\text {th }}\right.$ FYP $)$ & 2016 & Public & {$[100-103]$} \\
\hline \multirow{3}{*}{2} & \multirow{3}{*}{ Taiwan } & Taiwan productivity 4.0 & 2015 & Public & [72] \\
\hline & & Smart machinery & 2017 & Public & {$[24]$} \\
\hline & & Asia Silicon Valley development & 2017 & Public & {$[24]$} \\
\hline \multirow{4}{*}{3} & \multirow{4}{*}{ South Korea } & Manufacturing innovation (MI) 3.0 & 2014 & Public & [104] \\
\hline & & I-Korea 4.0 & 2018 & Public & [105] \\
\hline & & Innovation Platform Programme (IPP) & 2017 & Public & {$[106]$} \\
\hline & & Industrial value chain initiative (IVI) & 2016 & Private & {$[8,107]$} \\
\hline \multirow{5}{*}{4} & \multirow{5}{*}{ Japan } & Revitalization and Robot strategy (Robot revolution initiatives (RRI)) & 2015 & Private-public & {$[9,108-114]$} \\
\hline & & Society $5.0\left(5^{\text {th }}\right.$ Science and Technology Basic Plan), super smart society & 2016 & Public-private & {$[20,115]$} \\
\hline & & AI technology strategic conference (AITSC) & 2016 & Public & [116] \\
\hline & & IoT Acceleration Consortium (IoTAC) & 2015 & Private & {$[53]$} \\
\hline & & Industry $4.1 \mathrm{~J}$ & 2015 & Public & {$[104]$} \\
\hline \multirow{4}{*}{5} & \multirow{4}{*}{ Singapore } & Infocomm Media (ICM) 2025 & 2015 & Public & {$[117,118]$} \\
\hline & & RIE 2020 plan (research, innovation, and enterprise) & 2016 & Public & [119] \\
\hline & & Smart nation & 2014 & Public & [120] \\
\hline & & Service and digital economy technology roadmap (SDETRM) & 2018 & Public & [121] \\
\hline \multirow{5}{*}{6} & \multirow{5}{*}{ India } & Make in India (MII) & 2014 & Public & {$[122,123]$} \\
\hline & & Startup India & 2015 & Public & [124] \\
\hline & & Digital India (DI) & 2014 & Public & {$[125]$} \\
\hline & & Skill India (SI) & 2015 & Public & [126] \\
\hline & & Smart India & 2015 & Public & {$[124]$} \\
\hline \multirow{2}{*}{7} & \multirow{2}{*}{ Indonesia } & Making Indonesia 4.0 (MI 4.0) & 2017 & Public & {$[53]$} \\
\hline & & 2020 Go digital vision & 2015 & Public & {$[121]$} \\
\hline \multirow{2}{*}{8} & \multirow{2}{*}{ Russia } & National Technology Initiative (NTI) & 2015 & Public-private & {$[127]$} \\
\hline & & Data Economy Russia 2024 & 2017 & Public & {$[128]$} \\
\hline 9 & Thailand & Thailand 4.0 & 2016 & Public & [129] \\
\hline 10 & Turkey & Digital conversion association & 2016 & Public & {$[52]$} \\
\hline 11 & Vietnam & Strengthening the country's capacity to address industry 4.0 & 2017 & Public & {$[22]$} \\
\hline \multirow{2}{*}{12} & \multirow{2}{*}{ Malaysia } & Industry 4WRD or National Policy on Industry 4.0 & 2018 & Public & {$[130]$} \\
\hline & & Eleventh Malaysia plan & 2015 & Public & {$[72]$} \\
\hline \multirow[t]{2}{*}{13} & \multirow[t]{2}{*}{ Philippines } & Comprehensive Automotive Resurgence Strategy Programme & 2016 & Public & {$[131]$} \\
\hline & & Industry 4.0 Testlabs & 2017 & Public-private & {$[132]$} \\
\hline \multirow[t]{2}{*}{14} & \multirow[t]{2}{*}{ Australia } & Industry 4.0 prime minister taskforce & 2016 & Private & [132] \\
\hline & & The next wave of manufacturing & 2013 & Pubic & {$[73]$} \\
\hline
\end{tabular}

Table 5: Industry 4.0 initiatives launched in Middle East and Africa.

\begin{tabular}{|c|c|c|c|c|c|}
\hline $\mathrm{S} / \mathrm{N}$ & Country & Industry 4.0 initiatives & Year & Funding & References \\
\hline \multirow{4}{*}{1} & \multirow{4}{*}{ Israel } & Israel 2028 & 2018 & Public & {$[82,133]$} \\
\hline & & Israel innovation report 2017 & 2015 & Public & {$[82,133]$} \\
\hline & & Startup Nation & 2012 & Public & {$[133,134]$} \\
\hline & & Smart Dubai 2021 & 2017 & Public & {$[82]$} \\
\hline \multirow[t]{2}{*}{2} & \multirow[t]{2}{*}{ United Arab Emirates (UAE) } & UAE AI Strategy 2031 & 2018 & Public & {$[82]$} \\
\hline & & UAE's National Agenda 2021 & 2016 & Public & {$[135]$} \\
\hline \multirow{2}{*}{3} & Kingdom of Saudi Arabia & Saudi Vision 2030 & 2016 & Public & {$[135,136]$} \\
\hline & (KSA) & KSA's National Transformation Plan 2020 & 2016 & Public & [135] \\
\hline \multirow{2}{*}{4} & \multirow{2}{*}{ Qatar } & Qatar National Vision 2030 & 2016 & Public & {$[135]$} \\
\hline & & Qatar's National Development Strategy 2017-2022 & 2017 & Public & {$[135]$} \\
\hline 5 & Kuwait & New Kuwait Vision 2035 & 2016 & Public & {$[135]$} \\
\hline \multirow{2}{*}{6} & \multirow{2}{*}{ South Africa (SA) } & National E-strategy & 2017 & Public & {$[127]$} \\
\hline & & Intsimbi programme & 2018 & Public & {$[6]$} \\
\hline 7 & Morocco & $\begin{array}{c}\text { Digital Development Agency (L'Agence de Développement } \\
\text { Digital) (ADD) }\end{array}$ & 2017 & Public & [137-139] \\
\hline 8 & Rwanda & Centre for the Internet of things (IoT) & 2017 & $\begin{array}{l}\text { Public- } \\
\text { private }\end{array}$ & {$[6]$} \\
\hline
\end{tabular}


TABLE 6: Industry 4.0 initiatives for regional and international cooperation.

\begin{tabular}{lccccc}
\hline S/N & Region & Industry 4.0 initiatives & Year & Funding & References \\
\hline 1 & G20 & New industrial revolution (NIR) & 2014 & G20 members & {$[36,107]$} \\
2 & EU & Factories of the future & 2013 & EU members & {$[140,141]$} \\
& & Factories 4.0 and beyond & 2018 & EU members & {$[140]$} \\
3 & BRICS & BRICS skills development working group & 2016 & BRICS members & {$[3,6]$} \\
4 & GCC & BRICS digital cooperation on industrialization & 2019 & BRICS members & {$[142]$} \\
\hline
\end{tabular}

EU: European Union, BRICS: Brazil, Russia, India, China, and South Africa, and GCC: Gulf Cooperation Council.

TABLE 7: Industry 4.0 initiatives launched across the world.

\begin{tabular}{|c|c|c|c|c|c|c|}
\hline $\mathrm{S} / \mathrm{N}$ & Regions & $\begin{array}{l}\text { Total number of } \\
\text { countries }\end{array}$ & $\begin{array}{c}\text { Countries with industry } 4.0 \\
\text { initiative(s) }\end{array}$ & $\begin{array}{l}\text { Number of } \\
\text { initiatives }\end{array}$ & $\begin{array}{c}\text { Country } \\
(\%)\end{array}$ & $\begin{array}{c}\text { Region } \\
(\%)\end{array}$ \\
\hline 1 & $\begin{array}{l}\text { Latin America and the } \\
\text { Caribbean }\end{array}$ & 46 & 7 & 15 & 15 & 10 \\
\hline 2 & North America & 5 & 2 & 7 & 40 & 28 \\
\hline 3 & Europe & 47 & 25 & 41 & 53 & 37 \\
\hline 4 & Asia and Oceania & 55 & 14 & 39 & 25 & 17 \\
\hline 5 & Middle East and Africa & 72 & 8 & 15 & 11 & 8 \\
\hline 6 & Worldwide (overall) & 225 & 56 & 117 & 25 & - \\
\hline
\end{tabular}

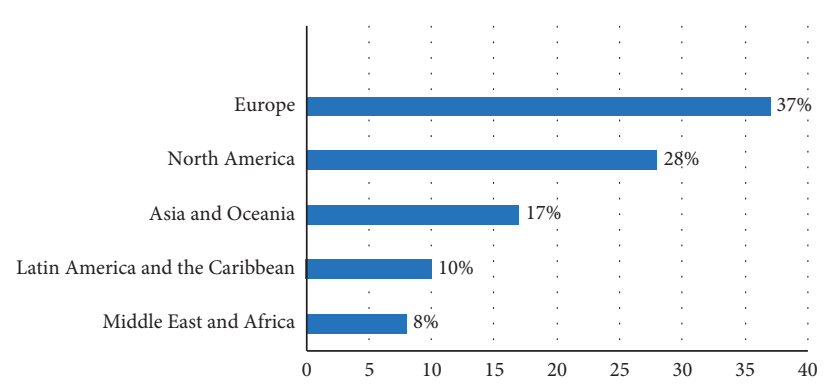

Figure 2: Industry 4.0 initiatives launched worldwide by region.
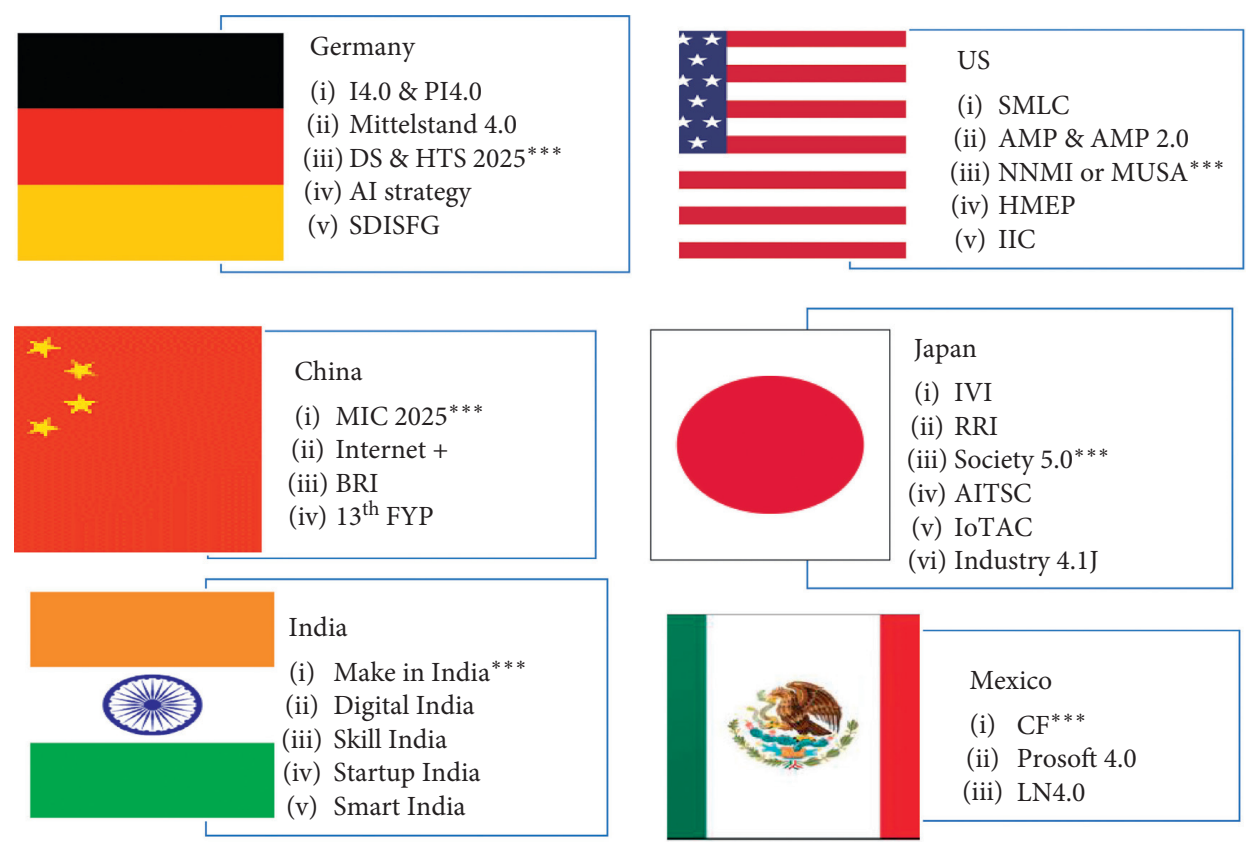

FIgURE 3: Industry 4.0 initiatives in the six selected countries. 
players from the science and research community, the private sector, and civil society. There are 12 research areas of the HTS 2025's mission-oriented approach including combating cancer, creating sustainable circular economies, and finding new sources for new knowledge [153].

\subsubsection{Manufacturing USA. Manufacturing USA (MUSA)} formally known as the National Network for Manufacturing Innovation (NNMI) is a successful program that has laid down the foundation for American manufacturing competitiveness for generations to come. It is the US federal government program for coordinating public and private investments and academia to improve the competitiveness and productivity of the US manufacturing through the creation of a robust network of manufacturing innovation institutes, each focused on a specific and promising advanced manufacturing technology area [60]. NNMI was introduced and launched in 2012 in the 2013 fiscal year (FY) budget by President Barrack Obama which was then renamed as Manufacturing USA on September 2016 by the Secretary of Commerce in the FY 2016. It was to raise awareness of the value of the program to industry, academia, nonprofits, the public, and the entire US manufacturing community, recognizing the program's impact on securing America's manufacturing future [61, 154]. The technology focus areas include additive manufacturing, biomanufacturing, nanomanufacturing, advanced materials, robotics, modeling and simulation, and real-time optimized production (smart manufacturing) [155]. The Manufacturing USA program is a network of 14 manufacturing institutes which are operational and implementing activities in their technology areas with each institute funded by a unique public-private partnership as shown in Table $8[60,156,157]$.

3.2.3. Made in China. Made in China 2025 (MIC 2025) is a national strategy of industry 4.0 , announced by China's State Council in May 2015 [92, 180]. The goal of MIC 2025 is to comprehensively upgrade, consolidate, and balance China's manufacturing industry, turning it into a global leader in innovation and manufacturing [181]. This will be achieved in three stages of strategic plans: (i) transforming China into a major manufacturing power by 2025; (ii) reaching an intermediate level among world's manufacturing powers by 2035; and (iii) becoming the leader among the world's manufacturing powers by 2049 [182]. MIC 2025 is to some extend inspired by the Germany's Industry 4.0 with reference to the inclusion of small and medium-sized enterprises (SMEs) in the supply chain and extensive use of new information technologies. MIC 2025 accentuates terms such as "indigenous innovations" and "self-sufficiency" which aggressively intends to increase the domestic market share of Chinese suppliers for basic core components and valuable materials by the year 2025 [183]. Thus, it imposes devastating fear of distorting global markets and negatively affects US and Germany [184]. MIC 2025 focuses on ten industrial sectors, namely, (i) advanced marine equipment and hightech vessels; (ii) advanced rail and equipment; (iii) agricultural machinery and technology; (iv) aviation and aerospace equipment; (v) biopharmaceuticals and high-end medical equipment; (vi) integrated circuits and new IT technology; (vii) high-end electronic equipment; (viii) highend manufacturing control machinery and robotics; (ix) low and new-energy vehicles; (x) new and advanced materials [182]. The key focused industry 4.0 technologies for MIC2025 include cyber physical systems (CPS), Internet of things (IoT), cloud computing, Big data, artificial intelligence, and robotics [53].

3.2.4. Society 5.0. Society 5.0 or super smart society was officially coined in the $5^{\text {th }}$ Science and Technology Basic Plan in FY2016-FY2020 by the Japanese's Council for Science, Technology, and Innovation which was affirmed by a cabinet choice in January 2016 [115]. Society 5.0 aims to provide a common societal infrastructure for prosperity based on an advanced service platform [185]. It also aims to realize a society where people enjoy life to the fullest. The Society 5.0 is not only for prosperity of Japan but also countries worldwide [20]. In addition, Society 5.0 aims to create a cyber physical society in which citizens' daily lives will be enhanced through increasingly close collaboration with artificially intelligent systems forming a super smart cyber physical system [186]. The Society 5.0 adverts to the new monetary society following the seeker gatherer (Society 1.0), peaceful agrarian (Society 2.0), modern social order (Society 3.0), and data social orders (Society 4.0) [185]. The technology focus of Society 5.0 includes [53] CPS, IoT, cyber security, cloud computing, Big data, artificial intelligence, and smart services/smart city.

3.2.5. Make in India. Make in India was initiated and launched in September 2014 by the Indian President as an initiative with the goal of positioning India in a forefront of global manufacturing and design [148]. It is a measure taken by the government of India to strengthen and improve competitiveness in the manufacturing sector by creating competitively priced and quality products. The flagship Make in India initiative aims to aggressively transform India into a manufacturing and technology hub. The prioritization of the manufacturing sector by this initiative was done after garnered considerable attention from all industry sectors which was based on the fact that the manufacturing sector of any economy is one of the key drivers of its employment and growth [124]. The key focus areas of the initiative include increased foreign direct investment (FDI) in manufacturing, minimize reliance on imports, enhance job opportunities, expand infrastructure, and promote technological evolution [148]. Its technology focus areas include industrial mobility, cloud platform, Big data analytics, and industrial cyber security. With these technologies, Make in India aims to achieve the best practices and strengthen India's competitiveness in 25 industry sectors including automobile, defense, aviation, biotechnology, chemicals, electrical machinery, electronics, food processing, oil and gas, and pharmaceuticals [122]. 
TABLE 8: Manufacturing USA institutes and the technology areas.

\begin{tabular}{|c|c|c|c|}
\hline $\mathrm{S} / \mathrm{N}$ & Technology & Institutes & References \\
\hline 1 & Additive manufacturing & $\begin{array}{c}\text { American Makes: the National Additive Manufacturing } \\
\text { Institute }\end{array}$ & {$[158-161]$} \\
\hline 2 & Digital manufacturing and design & $\begin{array}{c}\text { DMDII: Digital Manufacturing and Design Institute or MxD: } \\
\text { Manufacturing times Digital }\end{array}$ & {$[162]$} \\
\hline 3 & Lightweight metals manufacturing & LIFT: Lightweight Innovation For Tomorrow & {$[163,164]$} \\
\hline 4 & Wide bandgap power electronics manufacturing & $\begin{array}{l}\text { PowerAmerica: the Next Generation of Power Electronics } \\
\text { Manufacturing Innovation Institute }\end{array}$ & [165] \\
\hline 5 & Fiber-reinforced polymer composites & IACMI: Institute for Advanced Composite Manufacturing & {$[166]$} \\
\hline 6 & Integrated photonics manufacturing & $\begin{array}{l}\text { AIM Photonics: American Institute for Manufacturing } \\
\text { Integrated Photonics }\end{array}$ & {$[167,168]$} \\
\hline 7 & $\begin{array}{l}\text { Manufacturing thin flexible electronics devices and } \\
\text { sensors }\end{array}$ & $\begin{array}{c}\text { NextFlex: America’s Flexible Hybrid Electronics } \\
\text { Manufacturing Institute }\end{array}$ & [169] \\
\hline 8 & Fiber materials and manufacturing process & AFFOA: Advanced Functional Fabric of America Institute & {$[170,171]$} \\
\hline 9 & Smart manufacturing & $\begin{array}{c}\text { CESMII: Clean Energy Smart Manufacturing Innovation } \\
\text { Institute }\end{array}$ & {$[172,173]$} \\
\hline 10 & Biofabrication and manufacturing & $\begin{array}{l}\text { BioFabUSA: Advanced Regenerative Manufacturing Institute } \\
\text { (ARMI) }\end{array}$ & [174] \\
\hline 11 & Robotic manufacturing & ARM: Advanced Robotics for Manufacturing Institute & [175] \\
\hline 12 & Biopharmaceutical manufacturing & $\begin{array}{l}\text { NIIBML: National Institute for Innovation in Manufacturing } \\
\text { Biopharmaceuticals }\end{array}$ & {$[176]$} \\
\hline 13 & $\begin{array}{c}\text { Molecular chemical process intensification for clean } \\
\text { manufacturing }\end{array}$ & $\begin{array}{c}\text { RAPID: Rapid Advancement in Process Intensification } \\
\text { Deployment Institute }\end{array}$ & [177] \\
\hline 14 & $\begin{array}{l}\text { Sustainable reduction of carbon emission and } \\
\text { manufacturing with clean energy }\end{array}$ & $\begin{array}{l}\text { REMADE: Reducing Embodied-energy and Decreasing } \\
\text { Emissions }\end{array}$ & {$[178,179]$} \\
\hline
\end{tabular}

3.2.6. Crafting the Future. Crafting the future is the strategic initiative of industry 4.0 of Mexico founded in 2016 with partnership from government entities (science and academia), companies (Intel, Continental Automotive, Honeywell, and the Volkswagen Group), and trade associations [52]. Mexico is well known for its cost competitiveness advantage (i.e., low-cost labour force and high-volume production) that has made it become a world-class manufacturing hub [72]. With its industry 4.0 initiatives, Mexico aspires to be competitive with technological advanced manufacturing super power countries (UK, Germany, US, etc.). Crafting the future initiative focuses on the key industry 4.0 technologies which include Internet of things, Big data, cloud computing, system integration, collaborative robots, modeling, and simulation [52]. These strategies focus on establishing smart factories in the production process via technological advancements which prioritizes the main industry sectors such as chemical industry, aerospace economy, automotive industry, space industry, energy sector, and logistics [53].

Generally, Crafting the future initiative has a similar goal of attaining competitiveness as the rest of the initiatives. It can be concluded that both industry 4.0 initiatives focus on boosting domestic manufacturing and beefing up SMEs with the use of industry 4.0 technologies. The visible difference that exists between the industry 4.0 initiatives is mainly on the technology focus areas. Each initiative has different technology focus areas except for the "Digital Strategy and the High-Tech Strategy 2025" which have no technology focus areas. They focus on all technology areas because they are mainly research and development- (R\&D-) based initiatives. The industry 4.0 technologies adopted by each initiative are presented in Table 9.

\subsection{East African Community on Industry 4.0}

3.3.1. Definition of East African Community. The East African Community (EAC) is the regional intergovernmental organization of the Republics of Kenya, Uganda, Rwanda, Burundi, South Sudan, and the United Republic of Tanzania with its headquarters in Arusha, Tanzania. The EAC treaty was signed on 30 November 1999 and enacted on 7 July 2000 [187-189]. The main objective of the EAC is to introduce policies and programs to promote cooperation among its member states for mutual benefits in a wide range of areas including political, economic, social, cultural affairs, research and technology, defence, security, and legal and judicial affairs [190]. The EAC has strongly established a number of autonomous institutions including the East African Development Bank (EAfDB) and the Inter-University Council of East Africa (IUCEA). Both the EAfDB and IUCEA are headquartered in Kampala, Uganda. The EAfDB is mainly involved in the cross-border financing of regional development programmes and projects and small and medium scale industries. IUCEA serves to facilitate contact between the universities of East Africa, to provide a forum for discussion on a wide range of academic and other matters relating to higher education and to help maintain high and comparable academic standards in the universities of East Africa. The EAC vision is to become a globally competitive upper middle-income region by 2050 . This vision is the overall for its state partners, while each has its own vision as shown in Table 10 [189]. The availability of autonomous institutions and strategic visions is the strong asset for the EAC with some capabilities of supporting the race towards industry 4.0 . 
TABLe 9: Technology focus of industry 4.0 initiatives.

\begin{tabular}{|c|c|c|c|c|c|c|}
\hline Technology & DS \& HTS 2025 & MUSA & MIC 2025 & Society 5.0 & Make in India & $\mathrm{CF}$ \\
\hline IoT & 0 & 0 & $\checkmark$ & 0 & $\checkmark$ & $\checkmark$ \\
\hline Big data & $\mathrm{O}$ & $\mathrm{O}$ & $\checkmark$ & $\checkmark$ & $\checkmark$ & $\checkmark$ \\
\hline 3D printing & $\mathrm{O}$ & $\checkmark$ & $\mathrm{O}$ & $\mathrm{O}$ & $\mathrm{O}$ & $\mathrm{O}$ \\
\hline Cloud computing & O & O & $\checkmark$ & $\checkmark$ & $\checkmark$ & $\checkmark$ \\
\hline AI & $\mathrm{O}$ & $\mathrm{O}$ & $\sqrt{ }$ & $\checkmark$ & 0 & O \\
\hline CPS & $\mathrm{O}$ & $\mathrm{O}$ & $\sqrt{ }$ & $\checkmark$ & 0 & O \\
\hline Robots & 0 & 0 & $\checkmark$ & $\mathrm{O}$ & 0 & $\checkmark$ \\
\hline Modeling and simulation & $\mathrm{O}$ & $\checkmark$ & $\checkmark$ & O & O & $\checkmark$ \\
\hline Nanotechnology & 0 & $\checkmark$ & O & 0 & 0 & O \\
\hline Smart services & $\mathrm{O}$ & O & O & $\checkmark$ & O & O \\
\hline Smart factory & $\mathrm{O}$ & $\checkmark$ & $\mathrm{O}$ & $\mathrm{O}$ & $\mathrm{O}$ & $\mathrm{O}$ \\
\hline Mobile devices & $\mathrm{O}$ & O & O & O & $\checkmark$ & O \\
\hline Biotechnology & 0 & $\checkmark$ & $\mathrm{O}$ & O & O & $\mathrm{O}$ \\
\hline Cyber security & O & O & $\mathrm{O}$ & $\checkmark$ & $\checkmark$ & O \\
\hline Advanced materials & 0 & $\checkmark$ & $\mathrm{O}$ & 0 & $\mathrm{O}$ & 0 \\
\hline System integration & O & $\mathrm{O}$ & $\mathrm{O}$ & 0 & $\mathrm{O}$ & $\checkmark$ \\
\hline
\end{tabular}

AI: artificial intelligence, CPS: cyber physical system, and IoT: Internet of things.

TABLE 10: Strategic vision of the EAC's partner states.

\begin{tabular}{|c|c|c|c|}
\hline $\begin{array}{l}\text { Partner } \\
\text { state }\end{array}$ & Time frame & Strategic vision & References \\
\hline Uganda & Vision 2040 & Transform Ugandan society from peasant to a modern prosperous country & [191] \\
\hline Kenya & Vision 2030 & Globally competitive and prosperous Kenya with a high quality of life & {$[192]$} \\
\hline \multirow{2}{*}{ Rwanda } & Vision 2020 and & Become a middle-income country by 2020 & [193] \\
\hline & Vision 2050 & High standard of living & [194] \\
\hline Tanzania & Vision 2025 & $\begin{array}{l}\text { High quality of life anchored on peace, stability, unity, and good governance; rule of law, } \\
\text { resilient economy, and competitiveness }\end{array}$ & [195] \\
\hline $\begin{array}{l}\text { South } \\
\text { Sudan }\end{array}$ & Vision 2040 & Realizing freedom, equality, justice, peace, and prosperity for all & [196] \\
\hline Burundi & Vision 2025 & $\begin{array}{c}\text { Sustainable peace and stability and achievement of global development commitments in } \\
\text { line, Millennium Development Goals }\end{array}$ & [197] \\
\hline EAC & Vision 2050 & Attain a prosperous, competitive, secure, and politically united East Africa & {$[188]$} \\
\hline
\end{tabular}

3.3.2. Industry 4.0 Potentiality in EAC. The six major disruptive industry 4.0 technologies for Africa include Artificial intelligence (AI), the Internet of things (IoT), Big data, 3D printing, Blockchain, and drones [6]. These are being utilized in five main domains: agriculture, energy, industry, regional integration, and wellbeing [6]. The industry 4.0 adoption by EAC depends majorly on continental effort. At the African level, the preparedness to industry 4.0 can be witnessed from the launched industry 4.0 initiatives including "EU-AU Digital Task force," "Smart Africa," and "One Africa Network." Smart Africa is the program that the EAC is actively involved in. It was initiated and launched in 2013 by seven African Heads of State (Rwanda, Kenya, Uganda, South Sudan, Mali, Gabon, and Burkina Faso). At the EAC level, "One Network Area (ONA) roaming initiative" was initiated under the Northern Corridor Agreement. This could create an impetus environment for industry 4.0 technology in the EAC. At country level, only Rwanda has shown up while the rest such as Kenya, Uganda, and Tanzania have well demonstrated their potential with very strong Information and Communications Technology (ICT) policies [6].

The tendency of digitization and automation and the increased use of ICT have been fancied as the main concept of industry 4.0 [198-202]. Industry 4.0 demands further employee skills and competencies, such as ICT know-how, interdisciplinary competencies, and special personality traits. Besides industry 4.0 digital basis, knowledge and skills in ICT are compulsory as they paved way for this digital transformation [203-207]. ICT has a profusion of new technologies including cloud computing, Big data, and Internet of things (IoT) that are heightening automation and accelerating digitalization, networking, and connectivity; resulting in increased levels of industrial intelligence $[208,209]$. However, a poor ICT infrastructure in developing countries is thus one of the major challenges likely to debar governments from rapid adoption of industry 4.0 [127]. With these regards, ICT adoption among the EAC countries (Rwanda, Kenya, Uganda, Tanzania, Burundi, and South Sudan) was explored alongside industry 4.0.

(1) Rwanda. It is one of the three Africa countries (others being South Africa and Morocco) that have started developing industry 4.0 strategies alongside their ICT polices or created technology centres [138, 210]. The government of Rwanda has setup a "Centre for the Internet of Things (IoT)" in partnership with Inmarsat, the provider of global mobile 
satellite communications [6]. Centre for the Internet of Things (IoT) initiative aims to facilitate students' learning, to develop IoT prototypes and to carry out academic research in the field of potential IoT solutions. Further, it strives to accelerate the deployment of the IoT and smart city solutions. Within the ICT policy directed by the SMART Rwanda Master Plan 2015-2020, there are initiatives that have been launched by both the Rwandese government and private sectors. The major ICT innovative initiatives include the IREMBO platform, Digital Ambassadors Program, Kigali Innovation City, and Rwanda's ICT Hub Strategy 2024. The ICT policy has greatly developed Rwanda's cultural and creative industry to the extent of becoming a global economy [211]. However, manufacturing sectors have not yet been fully revived for the country to harvest its goal of competitiveness in the vision 2020 [212-214]. The new policy called "Made in Rwanda" is a holistic roadmap aimed at increasing economic competitiveness by enhancing Rwanda's domestic market through value chain development. It is aligned with Rwanda's aspiration to become an upper middle-income country by 2035 and higher income by 2050 [215]. This new policy has the capacity to strategize and promote industry 4.0 implementation in the country.

(2) Kenya. It is one of the African countries that have attained a lower middle-income status [190]. In the digital world, Kenya has been monikered as Africa's "Silicon Savanah" $[216,217]$. This has been due to the existence of a very strong focalized ICT policy underlined with its Vision 2030. In addition, technology in the mobile money system such as M-Pesa is unprecedented [218]. The M-Pesa (means mobile money) revolution has shaped Kenya's digital space and placed Kenya ahead of other developing countries in the deployment and use of digital technology [219, 220]. M-Pesa is a mobile payment platform launched in 2007 as a partnership between Safaricom (telecommunication (telco) company), Commercial Bank of Africa, and Commercial Banks in Kenya [221]. Another incredible turning point following M-Pesa revolution was the launch of a virtual savings platform called "M-Shwari" and has been replicated across EAC, with "M-Pawa" in Tanzania and "Mokash" in Uganda and Rwanda. Similarly, KCB M-Pesa and Equitel for mobile banking were launched [221]. Within the ICT policy, a Government Digital Payments Taskforce known as eCitizen was launched. Other ICT innovative platforms include Drumnet, mFarm, and Ushahidi [192, 222]. Despite the strong ICT policy in the country [223], Kenya's roadmap to industry 4.0 has remained unclear. Recently, the Kenya Association of Manufacturing (KAM) have proposed an agenda for securing the future of the manufacturing industry in Kenya on industry 4.0 and aims to develop a national policy framework and programme to implement industry 4.0 with sectoral bias [224]. This is still just on the paper work which will need to be implemented to show Kenya's readiness to industry 4.0. Another strong asset of Kenya is vitally dependent on the heavy investment in renewable energy both in wind and geothermal power projects [224]. This creates a very strong avenue for industry 4.0 deployment and implementation as energy 4.0 is centered around renewable energy.
(3) Uganda. It has a strategic Vision 2040 where industrialization is the priority. In contrast, the country came out with a national industrial policy which does not prioritize manufacturing. This made the manufacturing sector less competitive by focusing on mainly agroprocessing and lowvalue manufacturing [225-227]. Yet high-value manufacturing is the core for industrialization in most developing countries [225]. This is the reason why Uganda has not yielded positive results for industrialization in the past years [228]. The government of Uganda with a great potential has committed the country to develop a digital vision for Uganda known as Digital Uganda Vision (DUV). The DUV provides an overarching framework that responds to the Vision 2040 by providing a unified ICT policy direction [229]. The ICT policy driven by Vision 2040 is spearheaded by the Ministry of ICT which was purposely established to ensure growth and deployment of ICT in Uganda. Under the Ministry of ICT, there are several discussions being made on industry 4.0 from the policy viewpoint. In addition, the ICT officers are being trained on industry 4.0 technologies covering wide-ranging fields such as artificial intelligence (AI), Big data, Blockchain technologies, and cloud computing. Moreover, the Blockchain Association of Uganda has already been founded and the Nakawa Innovation Centre has been established [230]. This shows some sort of readiness to embrace industry 4.0 although there is still much to be done by Uganda to be ready for this industrial revolution colossus.

(4) Tanzania. This country, on the other hand, is improving productivity and competitiveness of its industrial sector which is directed by $5^{\text {th }}$ Phase Government Plan under Tanzania's Vision 2025 [231, 232]. The country has a strong ICT policy though not much have been reported on it [233]. However, the potential positive impacts of ICT are mainly in large-scale agriculture and firm's business processes [234]. One of the strongest assets of Tanzania is its ability to accommodate the concept of sustainability by going for more advanced and green technology, hence achieving increase in its productivity [235]. In addition, the Centre of Excellence for ICT in East Africa (CENIT@EA) has been launched in 2019 by the EAC in collaboration with the German Federal Ministry for Economic Cooperation and Development (BMZ) and hosted in Tanzania. It aims at providing relevant skills, capacities, and knowledge to shape the digital transformation.CENIT@EA is a consortium between the Nelson Mandela African Institution of Science and Technology (NM-AIST), the University of Oldenburg, and other East African and German universities and institutions [236]. This strong collaboration is very important for setting up profound requisite digital skills, and thus eventually lay good environment for industry 4.0 implementation.

(5) Burundi and South Sudan. These two EAC member countries have failed to perform in both economies and digital revolution due to unstable political weather of the countries which contributed to chronic poverty [190, 237, 238]. As a result, their developmental visions majorly aimed at restoring peace and stability, and they are 
the least competitive in the EAC and Africa at large [239]. These countries are yet to setup strong ICT policies to enable them start thinking about the disruptive industrial revolution. In addition, resources, finances, and skill workforce are vitally needed for industry 4.0 adaptation. Therefore, these countries need a lot of assistance from the international funding bodies to foster their readiness to industry 4.0.

3.3.3. Comparison of EAC Member Countries. All the EAC members have a strong ICT policy except Burundi and South Sudan. These two countries had limited studies about them, and they were excluded from the comparative study. Kenya and Rwanda are leading on ICT deployment. However, Rwanda is currently developing many new ICT innovative initiatives with the capabilities to harvest the competitiveness. Importantly, full exploitation of ICT potential in a country is instrumental regarding the realization of industry 4.0. However, the applications of ICT have been mainly centred around governance and services in each country as shown in Table 11.

On the side of industry 4.0 initiative, EAC member countries have shown daunting preparedness with the exception of Rwanda. However, on the other side of industry 4.0 technologies application, majority have responded well. The analysis of industry 4.0 technologies applications and startups was based on the study "Unlocking the African Potential for the Fourth Industrial Revolution" [6]. Evidence of the list of industry 4.0 technologies currently being applied in industrial sectors and the number of their startups shows that Kenya has the highest followed by Rwanda, Uganda, and then Tanzania. Tables 12 and 13 illustrate the current state of industry 4.0 technology applications and the startups in the major industrial sectors as per the year 2019, respectively.

3.4. Strengthening Industry 4.0 Adoption in EAC. Evidence from the series of industry 4.0 initiatives being launched from time to time shows that most developed countries have started enjoying the benefits of industry 4.0. Moreover, fabulous efforts are being enacted by these developed nations to ensure success in the industry 4.0 arena $[74,261,262]$. Yet, industry 4.0 is still a mystery to many developing and least-developed countries especially in Africa. A number of them are still stuck in industry 1.0 while others are struggling to transit to industry 2.0. These developing countries have first to enjoy the full benefits of even industry 2.0. Moreover, a number of them still lack access to electricity even for those that have it, it remains highly unreliable [18]. Seven strategies have been proposed for strengthening the industry 4.0 adoption in the EAC: education and training, public-private partnership (PPP) and policy innovation, open innovation initiative, research and development and innovation (R\&D\&I), collaboration and partnership, international and region cooperation, and small and medium enterprise focus as illustrated in Figure 4.

3.4.1. International Collaboration and Partnerships. Industry 4.0 disruption is leaving no room for status quo, and the developing countries or least-developed countries must get ready to leapfrog either willingly or forcefully. Industry 4.0 is a global phenomenon, which requires an international response [263]. Its adaptation and implementation are very expensive processes in both finance and requisite digital skills [264]. Therefore, international collaboration with those countries that are far much advanced in industry 4.0 could be a better option for faster industry 4.0 adaptation in the EAC. The benefits of collaboration and partnership can be taken from India as a life example. India has very strong collaboration with key player countries such as Germany (Indo-German) [265], Japan (Indo-Japan) [266], and United Kingdom (Indo-UK) [266]. Further, South Africa has also demonstrated very strong collaboration with other countries. For instance, "SA-EU strategic partnership" is a collaboration between South Africa and the European Union. The collaboration prospect covers many dimensions ranging from research (universities), technology transfer, skill development, investment in and mobilization of science, technology, and innovation capacities to benchmarking [267]. To this end, industry 4.0 is dependent on the collaboration and partnerships that combines digital and industrial knowledge. Therefore, forming of such partnerships enables the deployment of Industry 4.0 within the country as well as production companies [207].

3.4.2. International and Regional Cooperation. The international and regional cooperation plays roles in industry 4.0 adoption and implementation among countries. A number of international cooperations around the globe are striving to ensure success of their member countries in the industry 4.0 arena. For instance, the BRICS which is the cooperation between Brazil, Russia, India, China, and South Africa have developed a number of working groups with initiatives to prepare its members for industry 4.0 disruptions [268, 269]. The same efforts are being enacted by other international or regional cooperations such as the European Union (EU) and the Cooperation Council for the Arab States of the Gulf (GCC). Therefore, it is necessary for countries to form strong cooperation or join the cooperation either at regional or international levels in order to enjoy the full benefits of industry 4.0 or to activate the technological leapfrogging for the case of least-developed countries. EAC is the regional intragovernmental political and economic union [270, 271], just like the GCC. The EAC should develop ingenious strategies that will prepare its members for industry 4.0 disruptions and to awaken least-developed members (Burundi and South Sudan). This is because cooperation among countries is an incredible instrument for leapfrogging into industry 4.0 paradise.

3.4.3. Education and Training. Although there are a number of collaboration platforms existing between the countries within or outside the EAC, new such platforms should be created with a focus on the ongoing digital transformation. It is actually the work of the governments to support the establishment of joint industry 4.0 collaboration platforms, centres of excellence, and incubators to alleviate the diffusion of knowledge and technology [272, 273]. However, at 
TABLE 11: Initiatives in the EAC launched within the ICT policies.

\begin{tabular}{|c|c|c|c|c|}
\hline Country & Initiatives & Year & Funding & Reference(s) \\
\hline \multirow{3}{*}{ Uganda } & ICT4Agric & 2017 & - & {$[240]$} \\
\hline & E-government (eTAX, mTrac, e-water) & - & Public & {$[241,242]$} \\
\hline & Mobile money platform (MTN, Airtel) & 2009 & Public-private & [243] \\
\hline \multirow{4}{*}{ Kenya } & M-Pesa & 2007 & Private & [221] \\
\hline & M-Shwari, M-Pawa, and Mokasa & 2012 & Private & {$[244,245]$} \\
\hline & Government Digital Payments Taskforce (eCitizen) or e-government & - & Public & {$[246,247]$} \\
\hline & PRIMR (Primary Math and Reading) & 2011 & Public-private & [248] \\
\hline \multirow{3}{*}{ Tanzania } & ICT4D or e-government agency & - & Public & {$[249,250]$} \\
\hline & E-transparency & 2009 & Public & [251] \\
\hline & E-government strategy 2013 & 2013 & Public & [252] \\
\hline \multirow{6}{*}{ Rwanda } & IREMBO e-government platform, one-stop e-government & 2015 & Public-private & {$[253-255]$} \\
\hline & Digital Ambassadors Program (DAP) & 2019 & Public & [256] \\
\hline & Kigali Innovation City (KIC) & 2016 & Public & {$[257,258]$} \\
\hline & Rwanda's ICT Hub Strategy 2024 & 2019 & Public & [259] \\
\hline & Tap\&Go Smartcard & 2015 & Public-private & [253] \\
\hline & Smart city Rwanda & 2019 & Public & [260] \\
\hline
\end{tabular}

TABLE 12: Application of industry 4.0 technologies in industrial sectors.

\begin{tabular}{|c|c|c|c|c|}
\hline Industrial sector & Uganda & Kenya & Tanzania & Rwanda \\
\hline Agriculture & $\begin{array}{l}\checkmark \text { Big data } \\
\checkmark \text { IBS } \\
\checkmark \text { IoT }\end{array}$ & $\begin{array}{c}\checkmark \text { AI } \\
\checkmark \text { Big data } \\
\checkmark \text { Drones } \\
\checkmark \text { IBS } \\
\checkmark \text { MS } \\
\checkmark \text { IoT } \\
\checkmark \text { Robots }\end{array}$ & $\begin{array}{c}\checkmark \text { Drones } \\
\checkmark \text { IoT }\end{array}$ & $\begin{array}{c}\checkmark \text { Big data } \\
\checkmark \text { IBS } \\
\checkmark \text { IoT }\end{array}$ \\
\hline Healthcare & $\begin{array}{c}\checkmark \text { AI } \\
\checkmark \text { Big data } \\
\checkmark \text { IoT }\end{array}$ & $\begin{array}{l}\checkmark \text { IBS } \\
\checkmark \text { MS } \\
\checkmark \text { IoT }\end{array}$ & $\checkmark$ Drones & $\begin{array}{c}\checkmark \text { AI } \\
\checkmark \text { Drones } \\
\checkmark \text { IBS } \\
\checkmark \text { MS } \\
\checkmark \text { IoT }\end{array}$ \\
\hline Industry & $\mathrm{ON} / \mathrm{A}$ & $\begin{array}{c}\checkmark \text { IBS } \\
\checkmark 3 \mathrm{D} \text { printing }\end{array}$ & $\mathrm{ON} / \mathrm{A}$ & $\checkmark$ Drones \\
\hline Energy & $\begin{array}{l}\checkmark \mathrm{MS} \\
\checkmark \mathrm{IoT} \\
\end{array}$ & $\begin{array}{l}\checkmark \mathrm{MS} \\
\checkmark \mathrm{IoT} \\
\end{array}$ & $\checkmark$ IoT & $\checkmark$ IoT \\
\hline Education & $\begin{array}{c}\checkmark \text { IBS } \\
\checkmark \text { IoT } \\
\checkmark \text { Robots }\end{array}$ & $\begin{array}{c}\checkmark \text { AI } \\
\checkmark \text { Big data } \\
\checkmark \text { IBS } \\
\checkmark \text { MS } \\
\checkmark \text { IoT } \\
\end{array}$ & $\begin{array}{l}\checkmark \text { IBS } \\
\checkmark \text { IoT }\end{array}$ & $\begin{array}{l}\checkmark \text { Big data } \\
\checkmark \text { IoT }\end{array}$ \\
\hline Crosscutting & $\begin{array}{c}\checkmark \text { IoT } \\
\checkmark \text { Drones } \\
\end{array}$ & $\checkmark$ Drones & $\checkmark$ Drones & $\checkmark$ Drones \\
\hline MSFI & $\begin{array}{l}\checkmark \text { IoT } \\
\checkmark \text { MS } \\
\checkmark \text { IBS }\end{array}$ & $\begin{array}{c}\checkmark \checkmark \text { Blockchain } \\
\checkmark \text { Big data } \\
\checkmark \text { IoT } \\
\checkmark \text { 3D printing } \\
\checkmark \text { MS } \\
\checkmark \text { IBS }\end{array}$ & $\begin{array}{c}\checkmark \text { Blockchain } \\
\checkmark \text { IoT } \\
\checkmark 3 \mathrm{D} \text { printing } \\
\checkmark \text { MS } \\
\checkmark \text { IBS }\end{array}$ & $\begin{array}{c}\checkmark \text { Blockchain } \\
\checkmark \text { Big data } \\
\checkmark \text { MS } \\
\checkmark \text { IBS }\end{array}$ \\
\hline
\end{tabular}

IBS: Internet-based services, IoT: Internet of things, AI: artificial intelligence, MS: mobile services, N/A: not available, and MSFI: Modernized Services and Financial Inclusion.

the university level, joint research programs and exchange programs should be created to surrogate the skilling of labour force in the deployment of industry 4.0 infrastructures [274]. So far so good, as there are many student and staff exchange programs in the EAC. For example, the German
Academic Exchange Service (DAAD) which is currently strengthening the learning of students majorly in technology and engineering [274]. However, more of these programs should focus particularly on harnessing industry 4.0 technologies from perspectives of their development to 
TABLE 13: Industry 4.0 technologies with startups in the EAC.

\begin{tabular}{lcccc}
\hline Technology & Uganda & Kenya & Tanzania & Rwanda \\
\hline IoT & $\checkmark$ & $\checkmark$ & $\checkmark$ & $\checkmark$ \\
Big data & $\checkmark$ & $\checkmark$ & $\bigcirc$ & $\checkmark$ \\
3D printing & $\bigcirc$ & $\checkmark$ & $O$ & $\bigcirc$ \\
AI & $\checkmark$ & $\checkmark$ & $\checkmark$ & $\checkmark$ \\
Robots & $\bigcirc$ & $\checkmark$ & $\bigcirc$ & $\bigcirc$ \\
Drones & $\checkmark$ & $\checkmark$ & $\checkmark$ & $\checkmark$ \\
Blockchain & $\checkmark$ & $\checkmark$ & $\checkmark$ & $\checkmark$ \\
\hline
\end{tabular}

IoT: Internet of things and AI: artificial intelligence.

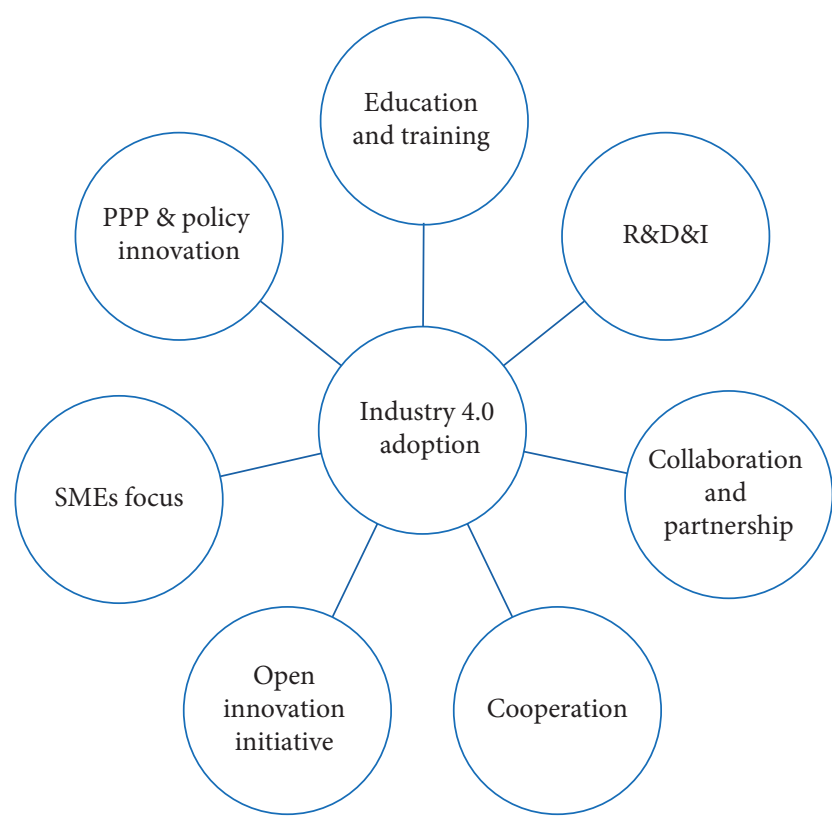

Figure 4: Strategies for industry 4.0 adoption in the EAC.

applications. Besides education, training is prerequisite for industry 4.0 adoption as it demands new set of kills from the workforce. The practical example can be witnessed from a number of countries including India which launched an industry 4.0 skill development initiative called Skill India [126]. Similarly, the BRICS Cooperation also has an industry 4.0 skill development working group which aims to develop the digital skills among its partner countries [3]. In this respect, the government and private sectors should heavily invest in training and information activities to train operators [74]. Otherwise, the EAC countries would remain technologically obsolete with respect to their competitors.

3.4.4. Open Innovation Initiative. A lucrative strategy to toughen the adoption of industry 4.0 within the private sector and academic entities is through joining open innovation initiatives and technology membership organizations. One of the examples is "Accenture open innovation initiative." It is a leading global initiative, providing a broad range of services and solutions in strategy, consulting, digital, technology, and operations [275]. This initiative is capable of boosting large companies as well as small high- tech firms and startups, hence laying solid grounds for industry 4.0 adaptation $[276,277]$. Besides, the Industrial Internet Consortium (IIC) is an internationally recognized open technology membership organization that provides a common understanding to promote interpretation and deployment of industrial internet of things (IIoT) among companies through published guidelines, reference frameworks, and specifications [278]. The IIC was founded in 2014 by five US's giant high-tech companies (GE, IBM, Cisco, AT\&T, and Intel) [279]. Many companies around the world are currently enjoying the benefits from such an astonishing organization. Innovations are essential for successful entry into the era of industry 4.0, and many governments try to promote innovation. However, corporate leaders of companies cannot easily determine innovative initiatives, as they are time consuming, costly, and likely to fail, which is dubbed as a "leadership gap" in an organization [280, 281]. Therefore, joining or being part of already established innovative initiatives is the option for the companies to benefit and sustain their competitiveness in the current dynamic business environment.

\subsubsection{Research, Development, and Innovation (R\&D\&I).} R\&D\&I has become an unprecedented strategy for beefing up industry 4.0 adoption at all levels (education, industry, country, and regional). The governments should emphasize more on science, technology, and innovation (STI) to strengthen research and development which builds a strong ecosystem for industry 4.0 adoption in EAC countries. In the light, feasible examples can be observed from the US and Germany. With the US, it has the Manufacturing USA initiative which launched 14 institutes focusing on research and development [155], while the Germany's High-Tech Strategy 2025 has a mission-oriented approach with 12 research areas including finding new sources for new knowledge and combating cancer [153]. Tout ensemble, there is a need for the governments and higher education to bridge the research gaps and gain opportunities for country's development by fully developing the research agenda of industry 4.0 [282]. So, by applying the macroeconomic indicator, the implementation of R\&D\&I results and industry 4.0 influence in EAC countries can be measured [283].

\subsubsection{Public-Private Partnership and Policy Innovation.} Sound government, corporate, academic, and civil society leadership and collaboration (private-public partnership) capabilities to respond to technological, market, and other change requirements are remarkably emblematic of industry 4.0 adoption in a country $[121,284]$. The ICT policy will have its limits very soon as industry 4.0 disruption is progressing. For this reason, the EAC needs to consider an industry 4.0 strategy alongside the ICT policy to be successfully competitive. This calls for the governments to rethink about their leadership infrastructure. There is a need for structural transformation by developing national policies on industry 4.0 , just like the ICT policy was formed by the EAC member countries [259]. This is the strategy that has been adopted by 
many countries including Malaysia [130], Thailand [129], and India [123] to strengthen the adoption and penetration of industry 4.0. In this regard, the successful adoption of industry 4.0 truly relies on the ability of governments, business, and citizens to commit in supporting the transformation of the society into a modern and smart society driven by advanced technology, skills, innovation, and responsive policy [127]. Most importantly, all the policies must be fully compatible with the United Nation's Sustainable Development Goals (SDGs) in order to effectively deal with the challenges of industry 4.0 and ensure a sustainable economic growth [285].

3.4.7. Small and Medium Enterprises Focus. SMEs are considered as a backbone of the economy because of their strong position as an employer. Thus, they attract attention both from policy makers and scientists [286, 287]. In this respect, a great opportunity for the future lies in the transfer of industry 4.0 expertise and technologies in SMEs and original equipment manufacturers (OEMs). The practical example of SMEs fostering to ensure success in industry adoption can be seen from countries such as US, Germany, China, UK, and India [201, 288], as they have developed a collaboration network through SMEs manufacturing support programs within their initiatives including Manufacturing USA [60], Made in China 2025 [183], Mittelstand 4.0 [88, 89], Catapult Centres [27], and Make in India [148], respectively. The point is that industry 4.0 disruption requires totally different maturity models for SMEs to that of multinational enterprises having higher driving forces and lower barriers to industry 4.0. However, SMEs have many hurdles to adopt industry 4.0 technologies in its infancy [289]. Thus, it is the role of the government to develop a strong industry 4.0 roadmap for SMEs [209]. In most cases, organizational resistance at both employee and middle management levels can significantly hinder the introduction of industry 4.0 technologies, yet these technologies can also transform management functions [290]. Therefore, establishment of an innovative business model through learning factory concept and innovation laboratory development is central for industry 4.0 adoption in both SMEs and large companies [291, 292].

\section{Conclusions}

The present study has successfully explored industry 4.0 initiatives launched by countries worldwide based on an electronic literature survey. The estimated percentage of countries with the established industry 4.0 initiatives in regions might not depict the real-life percentage, as the study was solely dependent on the electronic literature and limited by the availability of published information. Moreover, only published papers in English were considered. Nevertheless, the study estimates the numbers of industry 4.0 initiatives launched in countries around the world. Evidences from the literature shows a number of countries have not yet launched industry 4.0 initiatives. The result of the present study highlights that the Europe region leads the world as half of its countries have established industry 4.0 strategies already. However, Middle East and Africa are still at nascent stages of adoption with only few countries having developed industry 4.0 initiatives. Industry 4.0 technologies and initiatives are the complementary DNA of industry 4.0. For this reason, implementing industry 4.0 technologies alone is just not enough to succeed in the industry 4.0 arena. Every country should ensure that industry 4.0 technologies adoption advances with launching of initiatives. This is what the industry 4.0 pioneer countries (Germany and US) have pursued and are currently focusing more on research and development in "science, technology, and innovation (STI)" as the promising strategy to harness sustainable competitiveness in the present dynamic business environment. Yet, the concept and the infrastructure of industry 4.0 have not been fully comprehended in EAC. This calls for strong collaboration and coordination with industry 4.0 pioneer and expert countries in order to acquire the indispensability such as skills, knowledge, technology development, and method design.

\section{Conflicts of Interest}

The authors declare that there are no conflicts of interest regarding the publication of this paper.

\section{Acknowledgments}

The authors OB and GT are grateful to the World Bank and the Inter-University Council of East Africa (IUCEA) for the scholarships awarded to them through the Africa Center of Excellence II in Phytochemicals, Textiles, and Renewable Energy (ACE II-PTRE) at Moi University, Kenya. The authors are grateful to Technopolis Group, Research ICT Africa, and Tambourine Innovation Ventures for their study on "Unlocking Potential of the Fourth Industrial Revolution in Africa" initiated by the African Development Bank (AfDB), which provided astonishing information on industry 4.0 potential in East Africa and made this electronic survey successful.

\section{References}

[1] Malaysia Productivity Corporation, Ready, Set, Go! The Race Towards Industry 4.0, MPC, Selangor, Malaysia, 2018.

[2] CGI Global, Industry 4.0: Making Your Business More Competitive, CGI Global, Montreal, Canada, 2017.

[3] Roland Berger, Skill Development for Industry 4.0, Roland Berger, Mumbai, India, 2016.

[4] World Economic Forum, The Digital Arab World: Understanding and Embracing Regional Changes in the Fourth Industrial Revolution, World Economic Forum, Cologny, Geneva, Switzerland, 2018.

[5] Roland Berger, Industry 4.0: The New Industrial Revolution How Europe will Succeed, Roland Berger, Munich, Germany, 2014.

[6] Technopolis \& Research ICT Africa and Tambourine Innovation Ventures, Unlocking the Potential of the Fourth Industrial Revolution in Africa, Technopolis Group, Abidjan, Côte d'Ivoire, 2019. 
[7] J. Basl, "Companies on the way to industry 4.0 and their readiness," Journal of Systems Integration, vol. 3, pp. 3-6, 2018.

[8] S. H. Moon, "Industry 4.0 for advanced manufacturing and its implementation," Eurasian Journal of Analytical Chemistry, vol. 13, no. 6, pp. 491-497, 2018.

[9] METI, Japan's Robot Strategy: Vision, Strategy and Action Plan, Japan's Economic Revitalization, Tokyo, Japan, 2015.

[10] K. Siau, Y. Xi, and C. Zou, "Industry 4.0: challenges and opportunities in different countries," Cutter Business Technology Journal, vol. 32, no. 6, pp. 6-14, 2019.

[11] O. Bongomin, G. Gilibrays Ocen, E. Oyondi Nganyi, A. Musinguzi, and T. Omara, "Exponential disruptive technologies and the required skills of industry 4.0," Journal of Engineering, vol. 2020, pp. 1-17, 2020.

[12] V. Alcácer and V. Cruz-machado, "Scanning the industry 4.0: a literature review on technologies for manufacturing systems," Engineering Science and Technology, an International Journal, vol. 22, no. 3, pp. 899-919, 2019.

[13] K. Schwab, The Fouth Industrial Revolution, World Economic Forum, Cologny, Geneva, Switzerland, 2016.

[14] S. Grassi, S. Pantekoek, and Y. Ringot, German Robots in China and the Alibaba Villages: Discussion Paper Based on a Conference on Intelligent Manufacturing and Work 4.0-Challenges and Perspectives in China, South East Asia and Germany, 2018.

[15] O. G. Daniel and M. H. Xu, Made in China 2025: Market Opportunities for EU SMEs, 2018.

[16] F. Qian, W. Zhong, and W. Du, "Fundamental theories and key technologies for smart and optimal manufacturing in the process industry," Engineering, vol. 3, no. 2, pp. 154-160, 2017.

[17] Manufuture High-Level Group, Manufuture Vision 2030: Competitive, Sustainable and Resilient European Manufacturing, 2018.

[18] UNIDO, Industry 4.0: Opportunities Behind the Challenge, Background paper, UNIDO, Vienna, Austria, 2017.

[19] J. K. Gerrikagoitia, G. Unamuno, E. Urkia, and A. Serna, "Digital manufacturing platforms in the industry 4.0 from private and public perspectives," Applied Sciences, vol. 9, no. 2934, pp. 1-12, 2019.

[20] B. M. Fukuyama, Society 5.0: Aiming for a New HumanCentered Society, pp. 47-50, Japan Spotlight, Japan, 2018.

[21] C.-C. Kuo, J. Z. Shyu, and K. Ding, "Industrial revitalization via industry 4.0 -a comparative policy analysis among China, Germany and the USA," Global Transitions, vol. 1, pp. 3-14, 2019.

[22] UNIDO, You Say You Want a Revolution: Strategic Approaches to Industry 4.0 in Middle-Income Countries, UNIDO, Vienna, Austria, 2018.

[23] K. B. Belton, D. B. Audretsch, J. D. Graham, and J. A. Rupp, Who Will Set the Rules for Smart Factories? Leadership in Information Governance Will Provide a First-Mover Advantage to the Nation's Manufacturing Sector, 2018.

[24] S. Takakuwa, I. Veza, and S. Celar, "Industry 4.0 in Europe and East Asia," in Proceedings of the 29th DAAAM International Symposium on Intelligent Manufacturing and Automation, pp. 61-69, Zadar, Croatia, October 2018.

[25] K.-D. Thoben, S. Lingua, and S. Wiesner, "Industrie 4.0 and smart manufacturing-a review of research issues and application examples," International Journal of Automation Technology, vol. 11, no. 1, pp. 4-16, 2017.

[26] D. Buhr and T. Stehnken, Industry 4.0 and European Innovatiion Policy, 2018.
[27] GMIS-PwC, The Future of Manufacturing-France, 2018.

[28] PwC, Transforming Australian Manufacturing: Preparing Businesses and Workplaces for Industry 4.0, PwC, Canberra, Autralia, 2019.

[29] BSR, A New Era: Optimizing Chinese Industry in the Age of Automation, BSR, San Francisco, CA, USA, 2017.

[30] EC-JRC, China-Challenges and Respects from an Industrial and Innovation Powerhouse, Brussels, Belgium, 2019.

[31] AMP2.0, Accelerating U.S. Advanced Manufacturing, Washington, DC, USA, 2014

[32] G. Aichholzer, W. Rhomberg, N. Gudowsky, F. Saurwein, and M. Weber, Industry 4.0: Foresight \& Technology Assessment on the Social Dimension of the Next Industrial Revolution, Vienna, Austria, 2015.

[33] G. Garcia, Artificial Intelligence in Japan: Industrial Cooperation and Business Opportunities for European Companies, Tokyo, Japan, 2019.

[34] Deloitte, Toward the Next Horizon of Industry 4.0: Accelerating Transformation Through Collaborations and Startups, Deloitte, London, UK, 2018.

[35] S. Ezell, A Policymaker's Guide to Smart Manufacturing, 2016.

[36] P. Radanliev, The Industrial Internet-of-Things in the Industry 4.0 Supply Chains: Literature Review and Future Trends, London, UK, 2019.

[37] CMTC and SMLC, Smart Manufacturing: The next Revolution in Manufacturing, 2015.

[38] Y. Lu, K. Morris, and S. Frechette, Current Standards Landscape for Smart Manufacturing Systems Current Standards Landscape for Smart Manufacturing Systems, 2016.

[39] BMWi, Digitising Manufacturing in the G20-Initiatives, Best Practice and Policy Approaches, BMWi, Berlin, German, 2017.

[40] OECD/UN/UNIDO, “Transforming industries: unleashing the potential of industry 4.0 in Colombia," in Production Transformation Policy Review of Colombia: Unleashing Productivity, pp. 117-140, OECD Publishing, Paris, France, 2019.

[41] State Council, Made in China 2025, 2015.

[42] L. Da Xu, E. L. Xu, and L. Li, "Industry 4.0: State of the art and future trends," International Journal of Production Research, vol. 56, no. 8, 2018.

[43] F. Kimura, R. Shrestha, and D. Narjoko, "the digital and fourth industrial revolution and ASEAN economic transformation," in Transforming and Deepening the ASEAN Community, F. Kimura, V. Anbumozhi, and H. Nishimura, Eds., pp. 1-23, ERIA, Jakarta, Indonesia, 2019.

[44] Standards Australia, Industry 4.0: An Australian Perspective, Australia, 2017.

[45] S. Kota and T. C. Mahoney, Manufacturing Prosperity: A Bold Strategy for National Wealth and Security, 2018.

[46] C. W. Wessner, 21st Century Manufacturing: The Role of the Manufacturing Extension Partnership Program, National Academy of Sciences, Washington, DC, USA, 2013.

[47] T. Omara, A. K. Kiprop, R. C. Ramkat et al., "Medicinal plants used in traditional management of cancer in Uganda: a review of ethnobotanical surveys, phytochemistry, and anticancer studies," Evidence-Based Complementary and Alternative Medicine, vol. 2020, no. 6, Article ID 3529081, 26 pages, 2020.

[48] GMIS-PwC, The Future of Manufacturing-Brazil, 2018.

[49] Deloitte, Insights about Digital Transformation and ICT Opportunities for Brazil: Report and Recommendations, Deloitte, São Paulo, Brazil, 2019. 
[50] Brasília, Brazilian Digital Transformation Strategy: E-Digital, 2018.

[51] World Economic Forum, Supply Chain 4.0: Global Practices and Lessons Learned for Latin America and the Caribbean, World Economic Forum, Cologny, Geneva, Switzerland, 2019.

[52] Ministry of Economy, Crafting the future: A Roadmap For Industry 4.0 in Mexico, Mexico City, México, 2016.

[53] M. Speringer and J. Schnelzer, Differentiation of Industry 4.0 Models: The 4th Industrial Revolution from different Regional Perspectives in Global North and Global South, Vienna, Austria, 2019.

[54] SMLC, Implementing 21st Century Smart Manufacturing: Workshop Submit Report, 2011.

[55] M. Bryner, Smart Manufacturing: The Next Revolution, 2012.

[56] M. P. Gallaher, Z. T. Oliver, K. T. Rieth, and A. C. O'Connor, Economic Analysis of Technology Infrastructure Needs for Advanced Manufacturing Smart Manufacturing, Gaithersburg, MD, USA, 2016.

[57] PCAST, President's Council of Advisors on Science and Technology Releases Report on Advanced Manufacturing, PCAST, Washington, DC, USA, 2011.

[58] SAM, Strategy for American Leadership in Advanced Manufacturing, USA, 2018.

[59] AMP, Report to the President on Capturing Domestic Competitive Advantage in Advanced Manufacturing, AMP, Washington, DC, USA, 2012.

[60] NNMI, National Network for Manufacturing Innovation (NNMI) Program Strategic Plan, 2016.

[61] Manufacturing USA, Annual Report, Washington, DC, USA, 2016.

[62] Manufacturing USA, Annual Report: Program Report and Summary of Institute Activities, Washington, DC, USA, 2017.

[63] C. A. Lipscomb, J. Youtie, P. Shapira, S. Arora, and A. Krause, "Evaluating the impact of manufacturing extension services on establishment performance," Economic Development Quarterly, vol. 32, no. 1, pp. 29-43, 2018.

[64] GAO, Manufacturing Extension Partnership: Centers Cite Benefits from Funding Change, but Impacts Hard to Distinguish from Other Factors, GAO, Washington, DC, USA, 2019.

[65] S. J. F. John, The Manufacturing Extension Partnership Program, Washington, DC, USA, 2019.

[66] R. M. Soley, Overview of the Industrial Internet Consortium, 2015.

[67] S. Mellor, The Industrial Internet: Opportunities, Disruptions and Standards, 2016.

[68] IIC, The Industrial Internet of Things Volume G1: Reference Architecture, 2019.

[69] IIC, Industrial Internet Reference Architecture Technical Report, 2015.

[70] Accenture, Winning with the Industrial Internet of Things: How to Accelerate the Journey to Productivity and Growth, 2015.

[71] A. Deol, K. Figueredo, S.-W. Lin, B. Murphy, D. Seed, and J. Yin, Advancing the Industrial Internet of Things, 2019.

[72] Y. Liao, L. Eduardo Rocha, F. Deschamps, G. Brezinski, and V. André, "The impact of the fourth industrial revolution: a cross-country/region comparison," Production, vol. 28, Article ID e20180061, pp. 1-18, 2018.

[73] K. Siau, Y. Xi, and C. Zou, Industry 4.0: Challenges and Opportunities, 2019.

[74] A. Petrillo, F. De Felice, R. Cioff, A. Petrillo, and F. De Felice, "Fourth industrial revolution: current practices, challenges, and opportunities," in Digital Transformation in Smart Manufacturing, pp. 1-20, InTech, Napoli, Italy, 2018.

[75] P. Darmayan and H. Banthien, French-German Institute for Industry of the Future, Paris, France, 2017.

[76] Nouvelle-france-industrielle, New France Industry, Paris, France, 2016.

[77] W. Terkaj and T. Tolio, The Italian Flagship Project: Factories of the Future, pp. 1-33, Springer International Publishing, Rome, Italy, 2019.

[78] V. Mařík, Industry 4.0-The Initiative for the Czech Republic, 2016.

[79] CARSA and PwC, Key Lessons From National Industry 4.0 Policy Initiatives in Europe, 2017.

[80] P. Radanliev, D. De Roure, R. Nicolescu, and M. Huth, A Reference Architecture for Integrating the Industrial Internet of Things in the Industry 4.0, Oxford, London, 2019.

[81] W. Naudé, A. Surdej, and M. Cameron, The Past and Future of Manufacturing in Central and Eastern Europe: The Past and Future of Manufacturing in Central and Eastern Europe, IZA DP No. 12141, Bonn, Germany, 2019.

[82] SG:D, The Future of Services: Global Scan of Roadmaps, 2018.

[83] Department of Business Enterprise and Innovation, Ireland' s Industry 4.0 Strategy 2020-2025: Supporting the Digital Transformation of the Manufacturing Sector and its Supply Chain, 2020.

[84] D. W. Mattauch, Digitising European Industries-Member States Profile, Munich, Germany, 2017.

[85] Communication Promoters Group of the Industry-Science Research Alliance and ACATECH, Securing the Future of German Manufacturing Industry: Recommendations for Implementing the Strategic Initiative Industrie 4.0, Munich, Germany, 2013.

[86] Digital Transformation Monitor, Germany: Industrie 4.0, 2017.

[87] H. Kagermann, R. Anderl, J. Gausemeier, G. Schuh, and W. Wahlster, Industrie 4.0 in a Global Context: Strategies for Cooperating with International Partners (Acatech STUDY), Munich, Germany, 2016.

[88] BMWi, Monitoring Progress in National Initiatives on Digitising Industry: Country Report, Berlin, Germany, 2019.

[89] K. Gyu-Pan, L. Hyong-Kun, K. Jonghyuk, and K. H. Ju, "The fourth industrial revolution in major countries and its implications of Korea: U.S., Germany and Japan cases," World Economics Journal, vol 8, p. 20, 2018.

[90] BMWi, Digital Strategy 2025, BMWi, Berlin, Germany, 2016.

[91] Digital-made-in.de, Shaping Digitalization Implimentation Strategy of the Federal Governemnt, Berlin, Germany, 2018.

[92] K. Koleski, The 13th Five-Year Plan, 2017.

[93] X. Betty, China Internet Plus Strategy, 2015.

[94] Y. Hong, "Pivot to Internet plus: molding china's digital economy for economic restructuring ?" International Journal of Communication, vol. 11, pp. 1486-1506, 2017.

[95] G. le Pere, "China's belt and road initiative: boosting trade opportunities for Sub-Saharan Africa," in Commonwealth Trade Hot Topics, no. 143, T. Soobramanien, Ed., The Commonwealth, London, UK, 2017.

[96] M. N. I. Sarker, M. A. Hossin, X. Yin, and M. K. Sarkar, "One belt one road initiative of China: implication for future of global development," Modern Economy, vol. 09, no. 04, pp. 623-638, 2018.

[97] H. Löchel and F. Nawaz, "The Belt and Road initiative of China: A critical analysis of its feasibility," Frankfurt, vol. 226, 2018. 
[98] V. Kong, S. G. Cochrane, B. Meighan, and M. Walsh, The Belt and Road Initiative-Six Years On, 2019.

[99] C. Hong and O. Johnson, Mapping Potential Climate and Development Impacts of China's Belt and Road Initiative: A Participatory Approach, 2018.

[100] KPMG, The 13th Five-Year Plan-China's Transformation and Integration with the World Economy: Opportunities for Chinese and Foreign Businesses, KPMG, Amstelveen, Netherlands, 2016.

[101] Y. U. Hong, "Reading the 13th five-year plan: reflections on China's ICT policy reading the 13th five-year plan: reflections on China's ICT Policy," International Journal of Communication, vol. 11, pp. 1755-1774, 2017.

[102] S. Kennedy and C. K. Johnson, Perfecting China, Inc.: The 13th Five-Year Plan, 2016.

[103] M. Aglietta and G. Bai, China's 13th Five-Year Plan in Pursuit of a "Moderately Prosperous Society", 2016.

[104] J.-L. Chen, "The cases study of "one belt and one road" and "made in China 2025" impact on the development of Taiwan's machine tool industry," International Business Research, vol. 11, no. 2, pp. 189-196, 2018.

[105] ICDK, I-Korea 4.0: Innovation Initiatives in Smart Cities and Healthcare, ICDK, Seoul, Korea, 2019.

[106] S. S. Kim and Y. S. Choi, "The innovative platform programme in South Korea: economic policies in innovationdriven growth," Foresight and STI Governance, vol. 13, no. 3, pp. 13-22, 2019.

[107] M. Choi, Japan on National Industrial Revolution (NIR): Direction and its Global Implication for Inclusive and Sustainable Industrial Development, Tokyo, Japan, 2019.

[108] D. Neumann, Human Assistant Robotics in Japan-Challenges and Opportunities for European Companies, Tokyo, Japan, 2016.

[109] J. P. Mcdonnell, Resuscitation: Japan's Search for Machines and their Meanings, The University of San Francisco, San Francisco, CA, USA, 2018.

[110] G. Sziebig and P. Korondi, "Effect of robot revolution initiative in Europe-cooperation possibilities for Japan and Europe," IFAC-PapersOnLine, vol. 48, no. 19, pp. 160-165, 2015.

[111] R. D. Atkinson, Which Nations Really Lead in Industrial Robot Adoption? 2018.

[112] Y. Yokokohji, "Assembly challenge: a robot competition of the industrial robotics category, World robot summit-summary of the pre-competition in 2018," Advanced Robotics, pp. 1-25, 2019.

[113] C. B. Frey and M. Osborne, The Great Escape: How Workforce Automation is the Answer to Japan's Secular Stagnation, 2013.

[114] P. Van der Weeën, Robotics in Japan, Tokyo, Japan, 2015.

[115] R. Carraz and Y. Harayama, Japan's Innovation Systems at the Crossroads: Society 5.0, pp. 33-45, 2018, Digital Asia.

[116] M. Sakong, "The progress of the fourth industrial revolution in Japan and its implications," Korea Institute for Industrial Economics \& Trade, vol. 22, no. 2, pp. 37-49, 2017.

[117] Rajah and Tann LLP, Public Consultation on Infocomm Media Masterplan 2025 Goal of the Masterplan, Singapore, 2014.

[118] Ministry of Communications and Information, Infocomm Media 2025, 2015.

[119] APEC, Compendium of Smart Manufacturing Policy and Regulatory Approaches in APEC, APEC, Kuala Lumpur, Malaysia, 2019.
[120] J. J. Woo, Technology and Governance in Singapore's Smart Nation Initiative, 2018.

[121] R. M. Mitra, Digital Transformation and Industry 4.0 in Southeast Asia, pp. 109-133, 2019, Digital Asia.

[122] Innovate UK, The India-UK Future Manufacturing Report: Exploring Joint Opportunity for Innovation and Growth, 2017.

[123] AIMA-KPMG, Industry 4.0: India Inc. Gearing up for Change, 2018.

[124] EY, Making India a World Class Automotive Manufacturing Hub, India, 2016.

[125] N. Kaka et al., Digital India: Technology to Transform a Connected Nation, India, 2019.

[126] G. Jujjavarapu, E. Hickok, and A. Sinha, AI and the Manufacturing and Services Industry in India, India, 2018.

[127] M. I. Manda and S. Ben Dhaou, "Responding to the challenges and opportunities in the 4th industrial revolution in developing countries," in ICEGOV2019, pp. 244-253, 2019.

[128] T. Salimova, N. Guskova, I. Krakovskaya, and E. Sirota, "From industry 4.0 to society 5.0: challenges for sustainable competitiveness of Russian industry," IOP Conference Series: Materials Science and Engineering Papers, vol. 497, Article ID 012090, pp. 1-7, 2019.

[129] GMIS-PwC, Industry 4.0: Building the Digital Industrial Enterprise, 2016.

[130] Ministry of International Trade and Industry (MITI), Industry 4WRD: National Policy on Industry 4.0, MITI, Kuala Lumpur, Malaysia, 2018.

[131] Grant Thornton, Industry 4.0: Transforming the Manufacturing Landscape, Grant Thornton, Mumbia, India, 2018.

[132] Prime Minister's Industry 4.0 Taskforce, Industry 4.0 Testlabs in Australia Preparing for the Future, Prime Minister's Industry 4.0 Taskforce, Hawthorn, Victoria, Australia, 2017.

[133] E. Tidha, S. Keynan, J. Siegman, and D. Paikowsky, Unlocking Industry 4.0 Potential: Transforming Through Startup-Manufacturer Collaborations and the Unique Role of the Israeli Startup Ecosystem, 2018.

[134] D. Getz and I. Goldberg, Best Practices and Lessons Learned in ICT Sector Innovation: A Case Study of Israel, Tel Aviv, Israel, 2016.

[135] EY, Unlocking the Digital Economy Potential of the Kingdom of Saudi Arabia, 2019.

[136] Kingdom of Saudi Arabia, Intergovernmental Group of Experts on E-commerce and the Digital Economy, Geneva, Switzerland, 2019.

[137] GMIS-PwC, The Future of Manufacturing-Morocco, 2018.

[138] S. El Hamdi and M. Oudani, "Morocco's readiness to industry 4.0," in Proceedings of the 8th International Conference on Science of Electronics, Technologies of Information and Telecommunications (SETIT'18), Smart Innovation, Systems and Technologies, Hammamet, Tunisia, 2020.

[139] K. K. Lou, F. Sadeski, and M. Lacave, Study on Unlocking the Potential of the Fourth Industrial Revolution in Africa: Case of Morocco, Paris, France, 2019.

[140] C. Santos, A. C. Barros, M. Araújo, and E. Ares, "Towards industry 4.0: an overview of European strategic roadmaps," Procedia Manufacturing, vol. 13, pp. 972-979, 2017.

[141] R. Davies, "Industry 4.0: digitalisation for productivity and growth," EPRS-PE 568.337, 2015.

[142] R. Banga and P. J. Singh, BRICS Digital Cooperation for Industrialization, 2019. 
[143] United Nations Department of Economic and Social Affairs Population Division, World Population Prospect 2019: Data Sources, 2019.

[144] G. Eder, Work 4.0: Automation and the European Labor Market, 2017.

[145] W. Schroeder, S. Greef, and B. Schreiter, Shaping Digitalisation: Industry 4.0-Work 4.0-Regulation of the Platform Economy, 2017.

[146] M. Schäfer, "The fourth industrial revolution: how the EU can lead it," European View, vol. 17, no. 1, pp. 5-12, 2018.

[147] European Parliament Office (EPO), Patents and the Fourth Industrial Revolution: The Inventions Behind Digital Transformation, EPO, Munich, Germany, 2017.

[148] ASSOCHAM, The Textiles \& Apparels Industry Contributing to Make in India, ASSOCHAM, New Delhi, India, 2015.

[149] BMBF, The new High-Tech Strategy Innovations for Germany, BMBF, Berlin, Germany, 2014.

[150] PwC, Digital Product Development 2025: Agile, Collaborative, AI Driven and Customer Centric, $\mathrm{PwC}$, Berlin, Germany, 2019.

[151] World Economic Forum, Accelerating the Impact of Industrial IoT in Small and Medium-Sized Enterprises: A Protocol for Action, Cologny, Geneva Switzerland, 2020.

[152] E. Windhagen, J. Bughin, J. Mischke, C. Baur, F. Mattern, and S. Forman, Driving German Competitiveness in the Digital Future, 2017.

[153] BMBF, The High-Tech Strategy 2025 Progress Report, BMBF, Berlin, Germany, 2019.

[154] F. S. J. John, The National Network for Manufacturing Innovation, 2016.

[155] D. M. Hart, S. J. Ezell, and R. D. Atkinson, Why America Needs A National Network for Manufacturing Innovation, Washington, DC, USA, 2012.

[156] GAO, Advanced Manufacturing: Innovation Institutes Have Demonstrated Initial Accomplishments, but Challenges Remain in Measuring Performance and Ensuring Sustainability, GAO, Washington, DC, USA, 2019.

[157] Manufacturing USA, Annual Report, 2018.

[158] America Makes, Bringing Brilliance and Innovation to American Manufacturing, America Makes, Youngtown, $\mathrm{OH}$, USA, 2017.

[159] America Makes, America Makes: National Additive Manufacturing Innovation Institute, America Makes, Youngtown, OH, USA, 2017.

[160] America Makes and ANSI, Standardization Roadmap for Additive Manufacturing, America Makes, Youngtown, $\mathrm{OH}$, USA, 2017.

[161] E. Todorov, R. Spencer, S. Gleeson, M. Jamshidinia, and S. M. Kelly, America Makes: National Additive Manufacturing Innovation Institute (NAMII), 2014.

[162] B. Beckmann, A. Giani, J. Carbone, P. Koudal, J. Salvo, and J. Barkley, "Developing the digital manufacturing commons: a national initiative for US manufacturing innovation," Procedia Manufacturing, vol. 5, pp. 182-194, 2016.

[163] L. E. Brown and J. Deloach, National Network for Manufacturing Innovation: Lightweight Metals Institute Overview, Detroit, MI, USA, 2016.

[164] B. J. Bichon, Lightweight Innovations for Tomorrow Institute Mission, Southwest, 2017.

[165] B. Y. D. M. Hart and P. L. Singer, Manufacturing USA at DOE: Supporting Energy Innovation, 2018.

[166] J. A. Hopkins, Institute for Advanced Composites Manufacturing Innovation (IACMI-The Composites Institute), Washington, DC, USA, 2020.
[167] N. M. Fahrenkopf, C. Mcdonough, G. L. Leake, Z. Su, E. Timurdogan, and D. D. Coolbaugh, "The AIM Photonics MPW: a highly accessible cutting edge technology for rapid prototyping of photonic integrated circuits," IEEE Journal of Selected Topics in Quantum Electronics, vol. 25, no. 5, pp. 1-6, 2019.

[168] T. L. Koch, "The American institute for manufacturing integrated photonics: advancing the ecosystem Douglas Coolbaugh," in Proceedings of the SPIE 9772, Broadband Access Communication Technologies X, p. 977202, San Francisco, CA, USA, February 2016.

[169] E. Forsythe and B. J. Leever, NextFlex: Flexible Hybrid Electronics Manufacturing, San Jose, CA, USA, 2016.

[170] AFFOA, The Fabric Revolution: From Fiber Devices to Fabric System, AFFOA, Cambridge, MA, USA, 2018.

[171] AFFOA, Transforming Fabrics and Textiles into Integrated Devices and System, AFFOA, Cambridge, MA, USA, 2016.

[172] J. Wetzel, Clean Energy Smart Manufacturing Innovation Institute ( CESMII) Overview: Accelerating the Smart Manufacturing Transformation, 2018.

[173] S. Miller, Smart Manufacturing and the Clean Energy Smart Manufacturing Innovation Institute ${ }^{T M}$ (CESMII), San Francisco, CA, USA, 2018.

[174] BioFabUSA, Manufacturing the Future of Biofabrication, BioFabUSA, Manchester, NH, USA, 2018.

[175] ARM, Accelerating the Manufacturing Renaissance with People and Robots Working Together, ARM, Pittsburgh, PA, USA, 2017.

[176] NIIMBL, The National Institute fr Innovation in Manufacturing Biophermaceuticals: Annual Report 20172018, 2017.

[177] RAPID, Working Together to Grow Stronger, 2017.

[178] REMADE, REMADE Institute: Technology Roadmap 2018, 2018.

[179] REMADE, REMADE Institute: Technology Roadmap 2019, 2019.

[180] J. Xiong, “Strategic plan of 'Made in China 2025' and its implementation," in Analysing the Impacts of Industry 4.0 in Modern Business Environments, pp. 1-23, IGI Global, Hershey, PA, USA, 2018.

[181] Chairman Marco Rubio, Made in China 2025 and the Future of American Industry.

[182] M. J. Zenglein and A. Holzmann, Evolving Made in China 2025: China's Industrial Policy in the Quest for Global Tech Leadership, 2019.

[183] J. Wübbeke, M. Meissner, M. J. Z. J. Ives, and B. Conrad, Made in China 2025: The Making of A High-Tech Superpower and Consequences for Industrial Countries, 2016.

[184] W. M. Morrison, The Made in China 2025 Initiative: Economic Implications for the United States, 2019.

[185] O. Onday, "Japan's society 5.0: going beyond industry 4.0," Journal of Business Economics, vol. 10, no. 2, pp. 2-7, 2019.

[186] M. E. Gladden, "Who will be the members of society 5.0? towards an anthropology of technologically posthumanized future societies," Social Sciences, vol. 8, no. 148, pp. 1-39, 2019.

[187] EAC, East African Community EAC Development Strategy (2011/12-2015/16), EAC, Arusha, Tanzania, 2011.

[188] EAC, EAC Sub-regional Input to the Eleventh Session of the United Nations Forum on Forests (UNFF), EAC, Arusha, Tanzania, 2014.

[189] S. Große-Puppendahl, Understanding Industrialisation and Youth Employment Policy in the East African Community: Regional Rhetoric, National Drive, 2017. 
[190] UNCTAD, East African Community Regional Integration: Trade and Gender Implications, UNCTAD, Geneva, Switzerland, 2018.

[191] S. M. Balyejjusa, "Uganda's vision 2040 and human needs promotion," Africa Development, vol. 40, no. 4, pp. 61-90, 2015.

[192] Republic of Kenya, Sector Plan for Science, Technology and Innovation: Revitalizing and Harnessing Science, Technology and Innovation for Kenya's Prosperity and Global Competitiveness, Nairobi, Kenya, 2017.

[193] Republic of Rwanda, Country Profile-Rwanda, Kigali, Rwanda, 2017.

[194] C. Gatete, The Rwanda We Want: Towards' Vision 2050, Kigali, Rwanda, 2016.

[195] H. E. Jakaya and M. Kikwete, Tanzania's Transformation and Vision 2025: Governing Economic Growth for Social Gain, London, UK, 2014.

[196] Government of the Republic of South Sudan, South Sudan Development Plan 2011-2013: Realsing Freedom, Equality, Justice, Peace and Prosperity for All, Juba, South Sudan, 2011.

[197] The Republic of Burundi, UNDP, Gitega, Burundi, 2011.

[198] W. S. Alaloul, M. S. Liew, N. A. W. A. Zawawi, I. B. Kennedy, and I. B. Kennedy, "Industrial revolution 4.0 in the construction industry: challenges and opportunities for stakeholders," Ain Shams Engineering Journal, vol. 11, no. 1, pp. 225-230, 2020.

[199] L. M. Fonseca, "Industry 4.0 and the digital society: concepts, dimensions and envisioned benefits," Proceedings of the International Conference on Business Excellence, vol. 12, no. 1, pp. 386-397, 2018.

[200] A. Chiarini, V. Belvedere, and A. Grando, "Industry 4.0 strategies and technological development: an exploratory research from Italian manufacturing companies," Production Planning \& Control, pp. 1-14, 2020.

[201] D. T. Matt, V. Modrák, and H. Zsifkovits, Industry 4.0 for SMEs: Challenges, Oportunities and Requirements, Palgrave Macmillan, Cham, Switzerland, 2020.

[202] L. Belli, L. Davoli, A. Medioli, P. L. Marchini, and G. Ferrari, "Toward industry 4.0 with IoT: optimizing business processes in an evolving manufacturing factory," Frontiers in ICT, vol. 6, pp. 1-14, 2019.

[203] J. W. Veile, D. Kiel, and J. M. Müller, "Lessons learned from Industry 4.0 implementation in the German manufacturing industry," Journal of Manufacturing Technology Management, pp. 1-21, 2019.

[204] J. Prinsloo, J. C. Vosloo, and E. H. Mathews, "Towards industry 4.0: a roadmap for the South African heavy industry sector," The South African Journal of Industrial Engineering, vol. 30, no. 3, pp. 174-186, 2019.

[205] D. Valle, N. Fabián, M. José, and F. Lima, “The use of ICT tools to support collaborative product development activities: evidences from Brazilian industry," Production, vol. 28, Article ID e20170099, pp. 1-13, 2018.

[206] S. J. Raharja, P. W. Tresna, and Rivani, "Adoption of information and communication technology on enhancing business performance: study on creative industry SMEs in Bandung city, Indonesia," Review of Integrative Business and Economics Research, vol. 8, no. 3, pp. 20-30, 2019.

[207] E. Winberg and J. Ahren, Industry 4.0 from a Technology Adoption Perspective: A Case Study at Sandvik Coromant, The Royal Institute of Technology, Stockholm, Sweden, 2018.

[208] Technology Innovation Productization, "Industry 4.0: engineering the interface with real world," WFEO-CIC Initative in Colabration with Indian Technology Congress, vol. 5, no. 1, 2017.

[209] E. Karimov and J. F. Abrahamsson, Industry 4.0 and Swedish SMEs: An Assessment of Current Maturity Level and Challenges, Lund University, Lund, Sweden, 2019.

[210] G. F. Mukwawaya and B. Emwanu, "Assessing the readiness of South Africa for industry 4.0-analysis of government policy, skills and education," in Proceedings of the International Conference on Industrial Engineering and Operations Management, pp. 1587-1604, Paris, France, July 2018.

[211] International Trade Centre, Creative Industries in Rwanda: Digital Paths to Global Markets, International Trade Centre, Geneva, Switzerland, 2019.

[212] P. Behuria, "Twenty-first century industrial policy in a small developing country: the challenges of reviving manufacturing in Rwanda," Development and Change, vol. 50, no. 4, pp. 1033-1062, 2019.

[213] Ministry of Trade and Industry, Government of Rwanda National Industrial Policy, 2011.

[214] P. Behuria, "Twenty-first century industrial policy in a small developing country: the challenges of reviving manufacturing in Rwanda," Development and Change, vol. 50, no. 4, pp. 1-30, 2019.

[215] Ministry of Trade and Industry, Made in Rwanda Policy, 2017.

[216] C. Akamanzi, P. Deutscher, and B. Guerich, Silicon Savannah: The Kenya ICT Services Cluster, 2016.

[217] D. Krésová, Can the Fourth Industrial Revolution-Industry 4.0-Hold the Future for Africa's Industrialisation? Lund University, Lund, Sweden, 2019.

[218] Deloitte, Industry 4.0; Is Africa Ready for Digital Transformation? Deloitte, London, UK, 2016.

[219] F. E. V. Onyango and H. Kesa, "The fourth industrial revolution: implications for hotels in South Africa and Kenya Abstract," Tourism, vol. 66, no. 3, pp. 349-353, 2018.

[220] C. Ntara, "An analysis of M-pesa use in international transactions an analysis of M-pesa use in international transactions," European Journal of Business and Management, vol. 7, no. 17, pp. 73-79, 2015.

[221] N. Ndung'u, Digital Technology and State Capacity in Kenya, Washington, DC, USA, 2019.

[222] Kenya ICT Board, Connected Kenya: 2017 Master Plan, Kenya ICT Board, Nairobi, Kenya, 2017.

[223] ITU, ICT centric Innovation Ecosystem Kenya: Country Review, ITU, Nairobi, Kenya, 2019.

[224] Kenya Association of Manufacturer, Manufacturing Priority Agenda 2018, Kenya Association of Manufacturer, Nairobi, Kenya, 2018.

[225] R. Ggoobi, B. M. Wabukala, and J. Ntayi, Economic Development and Industrial Policy in Uganda, Kampala, Uganda, 2017.

[226] M. Fowler and J. Rauschendorfer, "Agro- industrialisation in Uganda: current status, future prospects and possible solutions to pressing challenges," F-IH-UGA-006-1, Kampala, Uganda, 2019.

[227] L. Calabrese, F. G. Mutebi, and M. M. Parra, Industrial Development in Uganda: An Assessment of the Policy Framework, 2019.

[228] A. J. B. Muwanguzi, P. Olowo, A. Guloba, and J. Muvawala, "Industrialisation as a vehicle for Uganda to achieve a 1st world economy by 2040: a review of Uganda's industrialisation efforts," American Journal of Industrial and Business Management, vol. 8, no. 3, pp. 496-513, 2018. 
[229] A. Gillwald, O. Mothobi, A. Ndiwalana, and T. Tusubira, The State of ICT in Uganda, Kampala, Uganda, 2019.

[230] D. Ojok, B. Mukhone, and P. Enywaru, Managing the 4th Industrial Revolution in East Africa: Insights from the First Kampala Digitalization Forum, Kampala, Uganda, 2018.

[231] AfDB, Eastern Africa's Manufacturing Sector (Tanzania Country Report): Promoting Technology, Innovation, Productivity and Linkages, AfDB, Nairobi, Kenya, 2014.

[232] J. Kweka, Monitoring Policies to Support Industrialization inTanzania: An Update and Policy Recommendations, 2018.

[233] U. Salam, S. Lee, V. Fullerton, Y. Yusuf, S. Krantz, and M. Henstridge, Tanzania Case Study: Rapid Technological Change - Challenges and Opportunities Final Report, 2018.

[234] K. Mwantimwa, "ICT usage to enhance firms' business processes in Tanzania," Journal of Global Entrepreneurship Research, vol. 6, no. 46, pp. 1-23, 2019.

[235] E. Simon, S. L. Mwaseba, and M. S. Juma, "Industrialisation in Tanzania: the fate of manufacturing sector lies upon policies implementations," International Journal of Economics and Business Research, vol. 7, no. 3, pp. 71-78, 2018.

[236] CENIT@EA, Partnership Development Events, CENIT@EA, Dar-es Salaam, Tanzania, 2019.

[237] United Nations Economic Commission for Africa, The Country Profile on Burundi, ECA, Addis Ababa, Ethiopia, 2016.

[238] World Bank, Republic of Burundi: Addressing Fragility and Demographic Challenges to Reduce Poverty and Boost Sustainable Growth, World Bank, Washington, DC, USA, 2018.

[239] AfDB, South Sudan: A Study on Competitiveness and Cross Border Trade with Neighbouring Countries, AfDB, Abidjan, Côte d'Ivoire, 2013.

[240] UCC, State of Information Communications Technology (ICT) for Agricultural Innovations in Uganda, UCC, Kampala, Uganda, 2019.

[241] R. Waiswa and C. Okello-Obura, "To what extent have ICTs contributed to e- governance in Uganda?" Library Philosophy and Practice, vol. 1125, pp. 1-20, 2014.

[242] CIPESA, ICT in Governance in Uganda-Policies and Practices, Kampala, Uganda, 2015.

[243] A. Ndiwalana and F. F. Tusubira, What is Happening in ICT in Uganda: A Supply-and Demand-Side Analysis of the ICT Sector, Kampala, Uganda, 2012.

[244] T. Cook and C. Mckay, How M-Shwari Works: The Story So Far, Nairobi, Kenya, 2015.

[245] N. Kiiti and M. Hennink, The Use and Impact of M-Shwari as a Financial Inclusion Banking Product in Urban and Rural Areas of Kenya, 2016.

[246] C. D. Huggins and N. Frosina, "ICT-driven projects for land governance in Kenya: disruption and e-government frameworks," GeoJournal, 2016.

[247] CIPESA, ICT in Governance in Kenya-Policies and Practice, CIPESA, Nairobi, Kenya, 2015.

[248] B. Piper, E. Jepkemei, D. Kwayumba, and K. Kibukho, "Kenya's ICT policy in practice: the effectiveness of tablets and e-readers in improving student outcomes," FIRE: Forum for International Research in Education, vol. 2, no. 1, pp. 1$18,2015$.

[249] J. Yonazi, "Exploring facilitators and challenges facing ICT4D in Tanzania," Journal of e-Government Studies and Best Practices, vol. 2012, Article ID 703053, pp. 1-16, 2012.

[250] CIPESA, ICT in Governance in Tanzania-Policies and Practice, CIPESA, Kampala, Uganda, 2015.
[251] E. W. Lubua and M. Maharaj, "ICT policy and e-transparency in Tanzania," in Proceedings of the IST-Africa 2012 Conference, pp. 1-10, 2012.

[252] W. B. Hamad, "E-government for Tanzania: current projects and challenges," International Journal of Engineering Science, vol. 8, no. 1, pp. 15911-15918, 2018.

[253] CGAP, Global Landscape Study on P2G Payments: Summary of In-Country Consumer Research Conducted in Rwanda, CGAP, Kigali, Rwanda, 2016.

[254] J. D. Twizeyimana, H. Larsson, and Å. Grönlund, "E-government in Rwanda: implementation, challenges and reflections," International Journal of Electronic Governance, vol. 16, no. 1, pp. 19-31, 2018.

[255] P. Bakunzibake, Å. Grönlund, and G. O. Klein, "Organisational challenges in the implementation of 'one-s top' e-government in Rwanda," International Journal of Electronic Governance, vol. 17, no. 1, pp. 1-19, 2019.

[256] Digital Opportunity Trust, Digital Ambassador Program Proof of Concept, Digital Opportunity Trust, Kigali, Rwanda, 2019.

[257] UNCTAD, The Science, Technology and Innovation Policy (STIP) Reviews: Rwanda, UNCTAD, Kigali, Rwanda, 2017.

[258] UNCTAD, Kigali Innovation City: Project Profile, UNCTAD, Kigali, Rwanda, 2016.

[259] Ministry of Information Technology and Communications, ICT Hub Strategy: Rwanda's roadmap to Becoming a Leading ICT Hub in Africa, Kigali, Rwanda, 2019.

[260] Republic of Rwanda, Smart City Rwanda MasterPlan, Kigali, Rwanda, 2019.

[261] J. Nagy, J. Oláh, E. Erdei, D. Máté, and Ó. Popp, “The role and impact of industry 4.0 and the Internet of things on the business strategy of the value chain-the case of Hungary," Sustainability, vol. 10, no. 3491, pp. 1-25, 2018.

[262] S. V. Lobova, N. V. Bykovskaya, I. M. Vlasova, and O. V. Sidorenko, "Successful experience of formation of industry 4.0 in various countries," in Industry 4.0: Industrial Revolution ofthe 21st Century, Studies in Systems, Decision and Control, E. G. P. Et, Ed., pp. 121-129, Springer International Publishing AG, Berlin, Germany, 2019.

[263] M. Gastrow, The Fourth Industrial Revolution (4IR) is a Global Phenomenon, South Africa, 2018.

[264] International Finance Corporation, Digital Skills in SubSaharan Africa: Spotlight on Ghana, International Finance Corporati, Washington, DC, USA, 2019.

[265] D. B. Holtkamp and A. Iyer, Industry 4.0: The Future of IndoGerman Industrial Collaboration, 2017.

[266] FICCI, India Japan Roadmap Towards Realising Vision 2025, FICCI, New Delhi, India, 2018.

[267] UNIDO, What Can Policymakers Learn from Germany's Industrie 4.0 Development Strategy? UNIDO, Vienna, Austria, 2018.

[268] A. Kutu and H. Ngalawa, "Dynamics of industrial production in BRICS countries," International Journal of Financial Studies, vol. 8, no. 1, pp. 1-25, 2017.

[269] S. Menelau, F. G. L. Macedo, P. L. D. Carvalho, and T. G. Nascimento, "Mapping Mapeamento da produção científica da Indústria 4.0 no contexto dos BRICS: reflexões e interfaces," Cadernos EBAPE.BR, vol. 17, no. 4, pp. 10941114, 2019.

[270] P. Carvalho Júnior and B. Hoffman, Political Economy of Regional Integration in Sub-Saharan Africa, 2015.

[271] African Development Bank, East Africa Economic Outlook 2019: Macroeconomic Developments and Prospects, African Development Bank, Abidjan, Côte d'Ivoire, 2019. 
[272] T. Nagasawa, Accelerating Clean Energy Through Industry 4.0 Manufacturing the Next Revolution, Vienna, Austria, 2017.

[273] SAM, Advanced Manufacturing: A Snapshot of Priority Technology Areas Across the Federal Government Subcommittee for Advanced Manufacturing, Washington, DC, USA, 2016.

[274] B. Holtkamp and A. Iyer, Industry 4.0: The Future of IndoGerman Industrial Collaboration, Gütersloh, Germany, 2017.

[275] Accenture, Harnessing the Power of Open Innovation through Digital Collaboration, South Africa, 2016.

[276] Accenture, Open Innovation: Collaborating Successfully with Small High-Tech Firms, 2015.

[277] D. Manceau, J. Fabbri, and V. Moatti, Open InnovationWhat Behind the Buzzword; Analysing what Open Innovation Changes in the Way Companies Innovate in Terms of Partner Relationships, Internal Organization and Innovation Performance, 2011.

[278] S. R. Bader and M. Maleshkova, Structuring Reference Architectures for the Industrial Internet of Things, pp. 1-23, 2019.

[279] Industrial Internet Consortium, Industrial Internet of Things Volume G4: Security Framework, Industrial Internet Consortium, Needham, MA, USA, 2016.

[280] H. Yang, S. Y. Kim, and S. Yim, "A case study of the Korean government's preparation for the fourth industrial revolution: public program to support business model innovation," Journal of Open Innovation: Technology, Market, and Complexity, vol. 5, no. 35, pp. 1-18, 2019.

[281] UNCTAD, Digital Economy Report: Value Creation and Capture, Implications for Development Countries, UNCTAD, Geneva, Switzerland, 2019.

[282] C. G. Machado, M. P. Winroth, and E. H. D. Ribeiro da Silva, "Sustainable manufacturing in industry 4.0: an emerging research agenda," International Journal of Production Research, vol. 58, no. 5, pp. 1462-1484, 2020.

[283] J. Švarcová, T. Urbánek, L. Povolná, and E. Sobotková, "Implementation of R\&D results and industry 4.0 influenced by selected macroeconomic indicators," Applied Science, vol. 9, no. 1846, pp. 1-14, 2019.

[284] N. Krachtt, The Workforce Implications of Industry 4.0: Manufacturing Workforce Strategies to Enable Enterprise Transformation, University of Wisconsin-Platteville, Platteville, WI, USA, 2018.

[285] E. K. Zervoudi, "Fourth industrial revolution: opportunities, challenges, and proposed policies," in Industrial RoboticsNew Paradigms, pp. 1-25, IntechOpen, London, UK, 2020.

[286] L. Safar, J. Sopko, S. Bednar, and R. Poklemba, "Concept of SME business model for industry 4.0 environment," TEM Journal, vol. 7, no. 3, pp. 626-637, 2018.

[287] A. Issa, D. Lucke, and T. Bauernhansl, "Mobilizing SMEs towards industrie 4.0-enabled smart products," Procedia CIRP, vol. 63, pp. 670-674, 2017.

[288] E. Stephen, Why Manufacturing Digitalization Matters and How Countries are Supporting It, 2018.

[289] M. Prause, "Challenges of industry 4.0 technology adoption for SMEs: the case of Japan," Sustainability, vol. 11, no. 5807, pp. 1-13, 2019.

[290] D. Horváth and R. Z. Szabó, "Driving forces and barriers of Industry 4.0: do multinational and small and medium-sized companies have equal opportunities?" Technological Forecasting and Social Change, vol. 146, pp. 119-132, 2019.

[291] D. Ibarra, J. Ganzarain, and J. I. Igartua, "Business model innovation through industry 4.0: a review," Procedia Manufacturing, vol. 22, pp. 4-10, 2018.
[292] D. Grube, A. A. Malik, and A. Bilberg, "SMEs can touch Industry 4.0 in the smart learning factory," Procedia Manufacturing, vol. 31, pp. 219-224, 2019. 